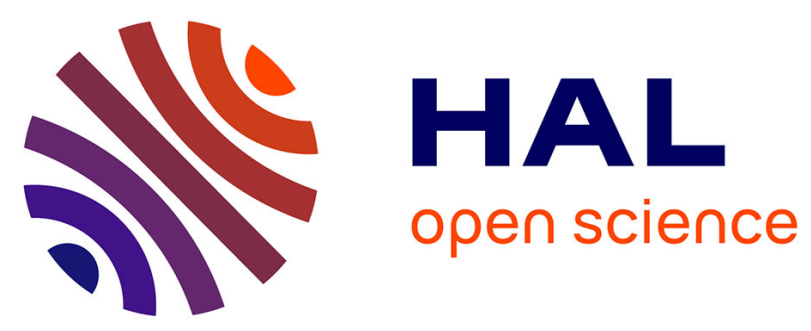

\title{
Kinetic reactive transport modelling of column tests for uranium In Situ Recovery (ISR) mining
}

Rose Ben Simon, Médard Thiry, Jean-Michel Schmitt, Vincent Lagneau, Valérie Langlais, Michel Bélières

\section{- To cite this version:}

Rose Ben Simon, Médard Thiry, Jean-Michel Schmitt, Vincent Lagneau, Valérie Langlais, et al.. Kinetic reactive transport modelling of column tests for uranium In Situ Recovery (ISR) mining. Applied Geochemistry, 2014, 51, pp.116-129. 10.1016/j.apgeochem.2014.09.014 . hal-01087953

HAL Id: hal-01087953

https://hal-mines-paristech.archives-ouvertes.fr/hal-01087953

Submitted on 27 Nov 2014

HAL is a multi-disciplinary open access archive for the deposit and dissemination of scientific research documents, whether they are published or not. The documents may come from teaching and research institutions in France or abroad, or from public or private research centers.
L'archive ouverte pluridisciplinaire HAL, est destinée au dépôt et à la diffusion de documents scientifiques de niveau recherche, publiés ou non, émanant des établissements d'enseignement et de recherche français ou étrangers, des laboratoires publics ou privés. 
Please cite this paper : Ben Simon et al.,2014, Kinetic reactive transport modelling of column tests for uranium In Situ Recovery (ISR) mining. Appl. Geochem.,

DOI: 10.1016/j.apgeochem.2014.09.014, Available online 2 October 2014.

\title{
Kinetic reactive transport modelling of column tests for uranium In Situ Recovery (ISR) mining
}

\author{
Rose Ben Simon ${ }^{(1)(4)}$, Médard Thiry ${ }^{(1)}$, Jean-Michel Schmitt ${ }^{(2)}$, Vincent Lagneau ${ }^{(1)}$, Valérie
} Langlais $^{(2)}$, Michel Bélières ${ }^{(3)}$

(1) Centre Géosciences, Mines Paris Tech, 35 rue St Honoré, 77305 Fontainebleau, France

(2) AREVA Mines, Geosciences Department, 1 place Jean Millier, 92084 Paris La Défense Cedex, France

(3) AREVA-SEPA, 1 avenue du Brugeaud, 87250 Bessines-sur-Gartempe, France

(4) present address : AUSY, 88 boulevard Gallieni, 92440 Issy-les-Moulineaux, France

Corresponding author : Médard Thiry, medard.thiry@mines-paristech.fr

Keywords:

modelling, uranium, leaching, test, mining, 


\begin{abstract}
The In Situ Recovery (ISR) mining method consists in mining ore by in situ chemical leaching with acid or alkaline solutions. Numerical modelling of the interaction between solution and rock is examined in order to improve the management of this process. Three different phenomena have to be taken into account in a numerical reactive transport simulation of uranium ISR mining: (1) the geochemical reactions; (2) the kinetics of these reactions, and (3) the hydrodynamic transport rate compared to the reaction kinetics. Two 'classical' types of leaching experiments were performed: (1) tests in batch reactors; and (2) extraction in flow-through columns. A comprehensive interpretation of the complete leaching test results (mineralogy of the samples and chemical analysis of leachates) led to the development of a conceptual model with reasonable assumptions about dissolution and precipitation reactions during the acid leach of the columns. This conceptual model was tested and validated by numerical modelling of the two types of laboratory experiments. Batch experiments were simulated with the geochemical code CHESS in order to model the leachate solutions and to calibrate the geochemical reaction paths and their kinetic laws. Column experiments were simulated with the coupled hydrodynamic and geochemical code HYTEC by using kinetic laws calibrated on batch experiments. The geochemical models with kinetics successfully simulated the trend of leachate' chemistry in the two types of experimental tests (batch and column). Numerical simulation of leaching tests enabled us to translate the chemical release sequence, observed during experiments, into a sequence of dissolution-precipitation reactions. Finally, it resulted in a proposal of a 1D hydrogeochemical transport model of the ISR process at laboratory-scale. Furthermore, a sensitivity analysis conducted on the 1D-calibrated model made it possible (1) to determine factors controlling leaching reactions; and (2) to quantify their respective influence on the uranium recovery in terms of acid consumption and leachate volume to treat in the plant. Although experimental and numerical simulation results do not perfectly fit the field-scale observations, it was possible to define not only the factors controlling uranium dissolution and the precipitation of secondary mineral phases in the deposit, but also to determine the relative importance of these factors.
\end{abstract}




\section{Introduction}

\subsection{Objectives}

Interest in the In Situ Recovery (ISR) mining method has grown considerably during the last 30 years (World Nuclear Association, 2012), because of its advantages over conventional methods (open-pit or underground mining) for the mining of low-grade deposits. The ISR method consists in ore mining with in situ chemical leaching by acid or alkaline solutions (Sundar, 1977; Kuzmanov, 1993; IAEA, 2001; Mudd, 2001; Commonwealth of Australia, 2010). The leaching solution is injected into the ore body through a number of wells ('injectors') and the uranium-enriched leachate is pumped out from nearby 'productor' wells. ISR takes place underground and its monitoring is therefore limited to the analysis of the pumped solution; core sampling inside the aquifer is generally avoided during production to minimize possible interference with the fluid circulation. Indeed, the phenomenology of ISR is very complex (chemical reactions, kinetic control and strong influence of hydrodynamic transport). Production efficiency requires an optimizing of the process in terms of uranium recovery, acid consumption, volume of leachates to treat in the plant and subsequent impacts on the aquifer. Leaching experiments and geochemical modelling have been proposed to study the leaching processes (Wood, 1978; Bommer and Schechter, 1979; Nigbor et al., 1982; Eary and Cathles, 1983; Lottering et al. 2008; Johnson et al., 2010, Johnson, 2011; Nos, 2011).

The aim of this study is to clarify the phenomenology of the ISR process through the use of a realistic reactive transport model in order to achieve increasingly efficient management of the ISR process in the near future. The reactive transport model is controlled by laboratory batch and flow-through experiments.

\subsection{Strategy}

Three different phenomena have to be taken in account for numerical simulations of uranium recovery by ISR: (1) the geochemical reactions occurring during the process, (2) the kinetics of these reactions, and (3) the hydrodynamic transport with respect to the reaction kinetics. Thus, the numerical model of the process is a system of differential equations describing the flow, the thermodynamic equilibria and the kinetics. The main difficulty is to determine coefficients and functions for ISR specific conditions. Therefore it is necessary to simplify the dependencies between functions to solve the problem. The coefficients have to be estimated - or better evaluated - by leaching experiments.

For this purpose two types of laboratory tests were conducted: (1) tests in batch reactors focusing on the main geochemical reactions and their respective kinetics, independently of transport considerations; and (2) 'classical' column-leaching tests by which geochemistry and transport could be combined to resemble the conditions of ISR exploitation (Fig. 1). 


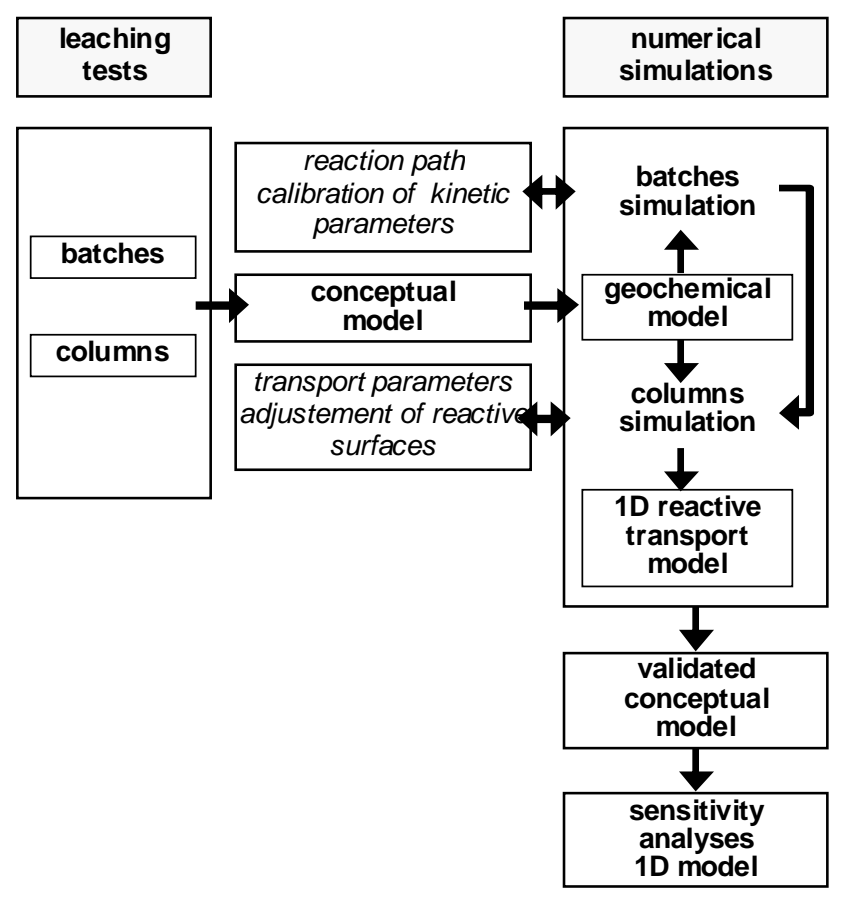

Figure 1: Synoptic diagram showing the modelling strategy: laboratory tests modelled to determine geochemical constants which are later used to build the reactive transport model.

The column test results (mineralogy of the samples and chemical analyses of leachates) led us to define a conceptual model of the process by making simple assumptions about dissolution and precipitation reactions occuring during the leaching of ore samples. This conceptual model was tested by simulating the different laboratory experiments. Batch experiments were first simulated with a thermodynamic geochemical speciation code, in order to reproduce the chemistry of leaching solutions and to calibrate the kinetic reaction laws. Column-leaching tests were simulated with a coupled hydrodynamic and geochemical code, using a direct application of the geochemical model calibrated with the batch experiments. This kinetic model allowed a successful simulation of the leachate evolution trend of both batch and column tests, and can therefore be considered reasonably constrained.

Numerical simulations of leaching tests were used to translate the chemical release sequence, observed during the experiments, into a dissolution-precipitation reaction sequence. It resulted in the proposal of a 1D-hydrogeochemical transport model of the ISR process at laboratory scale. Furthermore, sensitivity analyses conducted on the 1D-calibrated model allowed us (1) to determine the factors controlling leaching reactions, and (2) to quantify their respective influence on the uranium recovery in terms of acid consumption and volumes of leachates to treat in the plant. Finally, these sensitivity analyses led us to propose a simplification of the numerical simulation with the aim to develop in the near future a realistic reactive transport model of the ISR process at field scale. 


\section{Material and methods}

\subsection{Samples}

The uranium ore used for this study comes from the roll front type deposits of Tortkuduk (Chu-Sarysu Basin, Kazakhstan). A general description of these deposits can be found in Dahlkamp (2010) and Ben Simon (2011). The ore material is a silico-clastic sediment that presents the heterogeneities of this kind of deposit: sand layers of variable grain-sizes, claystone intercalations, as well as oxidized and reduced zones. A composite sample, representative of the average grain-size, mineralogy and uranium content of one of the deposits, was assembled to obtain homogeneous samples for all the successive tests. The composite sample is a poorly graded clayey sand, with an average grain-size of $0.34 \mathrm{~mm}$. XRD analyses show that the composite sample is composed mainly of quartz with minor amounts of microcline, albite, muscovite, pyrite and clay minerals (Table 1). Carbonate was not detected by XRD analysis; nevertheless chemical analyses show 0.01 weight\% of inorganic carbon (Table 2) that may correspond to about 0.016 weight\% of calcite/dolomite. The composite sample contains 572 ppm of uranium.

Note that the delay between sampling and reception of the samples in the laboratory led to a partial oxidation of the pyrite and uraninite into poorly crystallized iron and uranium oxyhydroxydes (most probably hematite-ferrihydrite and schoepite) and development of some accessory minerals such as jarosite and gypsum. Due to the powdery and disturbed nature of the drill samples, as well as to the high sulphuric-acid content of the column-leached samples, it was impossible to carry out SEM analyses to specify the nature and spatial arrangement of the secondary phases.

Table 1: Mineralogical composition of the composite sample used for the leaching tests.

\begin{tabular}{|c|c|c|c|c|c|c|c|}
\hline \multirow{7}{*}{ 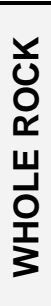 } & FRACTIONS & $>1.0 \mathrm{~mm}$ & $1.0-0.5 \mathrm{~mm}$ & $0.5-0.2 \mathrm{~mm}$ & $0.2-0.1 \mathrm{~mm}$ & $0.1-0.05 \mathrm{~mm}$ & $<0.05 \mathrm{~mm}$ \\
\hline & QUARTZ & 100 & 100 & 100 & 95 & 95 & 95 \\
\hline & MICROCLINE & * & * & * & 5 & 5 & 5 \\
\hline & ALBITE & & & & $\star \star \star *$ & $* * * *$ & $* * *$ \\
\hline & MUSCOVITE & & & & & $\star *$ & ** \\
\hline & PYRITE & ** & & & ** & ** & $\star * \star *$ \\
\hline & CLAY MIN. & & & & * & ** & $\star * *$ \\
\hline
\end{tabular}

\begin{tabular}{|c|c|}
\hline \multicolumn{2}{|c|}{$\begin{array}{l}\text { CLAY MINERALS } \\
<0.05 \mathrm{~mm}\end{array}$} \\
\hline KAOLINITE & 25 \\
\hline ILLITE & 10 \\
\hline SMECTITE & 60 \\
\hline ILL/SMECT & 5 \\
\hline
\end{tabular}

Table 2: Chemical composition of the composite sample used for the leaching tests.

\begin{tabular}{|c|c|c|c|c|c|c|c|c|c|c|c|c|c|}
\hline $\mathrm{Al}_{2} \mathrm{O}_{3}$ & $\mathrm{Na}_{2} \mathrm{O}$ & $\mathrm{K}_{2} \mathrm{O}$ & $\mathrm{SiO}_{2}$ & $\mathrm{Fe}_{2} \mathrm{O}_{3}$ & MnO & MgO & $\mathrm{CaO}$ & $\mathrm{TiO}_{2}$ & $\mathrm{P}_{2} \mathrm{O}_{5}$ & $S_{\text {tot }}$ & $\mathrm{CO}_{3}{ }^{-}$ & $\mathbf{C}_{\text {org }}$ & $\mathbf{U}$ \\
\hline \multicolumn{12}{|c|}{ wt \% } & \multicolumn{2}{|c|}{ ppm } \\
\hline 2.59 & 0.10 & 0.80 & 93.14 & 1.11 & $<0.02$ & 0.07 & 0.12 & 0.11 & 0.02 & 0.47 & 0.01 & 442 & 572 \\
\hline
\end{tabular}

\subsection{Leaching tests}

The leaching solutions were simplified compared to the solutions injected in the mining plant which are more mineralized and complex because they are recycled and simply re-acidified in the course of the 
process. On the one hand, the simplification of the leaching solution simulates the beginning of the ISR operation when acid is injected into the groundwater and on the other hand it allows the successive geochemical reactions to be decomposed with a minimum of disturbance. Besides, less mineralized solutions ensure a better analytical precision concerning weak chemical variations.

\subsubsection{Batch experiments}

Batch experiments were made with a liquid/solid ratio (L/S) of 4 . Tests were carried out in 1 litrepolypropylene batch reactors, combining $200 \mathrm{~g}$ of sample and $800 \mathrm{~mL}$ of acidic solution under inert atmospheric conditions $\left(\mathrm{N}_{2}\right)$. Inert atmosphere was chosen in order to better simulate the ISR process that occurs underground without renewal of oxygen. Nevertheless, in the experiments as well as in the real ISR process, the initial acidic solution contains dissolved oxygen more or less at equilibrium with the atmosphere. Leaching solutions were composed of deionised water with sulphuric acid $\left(\mathrm{H}_{2} \mathrm{SO}_{4}\right)$. Two sets of experiments were carried out with a $\mathrm{H}_{2} \mathrm{SO}_{4}$ concentration of $8 \mathrm{~g} / \mathrm{L}$ and of $15 \mathrm{~g} / \mathrm{L}$ in order to compare dissolution rates in different acidity conditions.

The reactors were closed and slightly stirred in a rotary shaker. Batch tests were performed for 1 to 216 hours (nine days), and duplicates were made for some of the tests. At the end of each test, pH, redox potential (Eh) and electrical conductivity were measured. The leachates were filtered to $0.45 \mu \mathrm{m}$ for chemical analyses (chromatography and ICP MS).

\subsubsection{Column experiments}

Column-leaching experiments were carried out in vertical PVC columns $4.4 \mathrm{~cm}$ in diameter and $50 \mathrm{~cm}$ in length packed with the composite sample, at atmospheric pressure. The input solution was percolated upwards to avoid pore plugging by gas. Leachates were collected over periods of 6 hours and were weighed in order to calculate the average percolation rate. $\mathrm{Eh}, \mathrm{pH}$ and conductivity were measured and leachates filtered to $0.45 \mu \mathrm{m}$ for chemical analyses. The flow rate was expressed in Pore Volume (PV) that means the volume of the pores in the sample, and was set at approximately 1 PV per day, which corresponds to the average flow rate applied during ISR mining at the Tortkuduk site. Because of this low flow rate it was necessary to blend several 6 hour aliquots to reach the volume needed for chemical analysis. To simulate the conditions of the in situ operation, $\mathrm{H}_{2} \mathrm{SO}_{4}$ was added ( 8 and $15 \mathrm{~g} / \mathrm{L}$ ) to a synthetic solution approximating the composition of the real groundwater (Table 3).

Table 3: Chemical composition of the synthetic groundwater solution (resembling the Tortkuduk groundwater, Safege 2001) used for column percolation.

\begin{tabular}{|c|c|c|c|c|c|c|c|c|c|}
\hline $\mathrm{Ca}^{2+}$ & $\mathbf{M g}^{2+}$ & $\mathrm{K}^{+}$ & $\mathrm{Na}^{+}$ & $\mathbf{F e}^{2+}$ & $\mathrm{Fe}^{3+}$ & $\mathrm{Cl}^{-}$ & $\mathbf{S O}_{4}{ }^{2-}$ & $\mathbf{H C O}_{3}{ }^{-}$ & $\mathbf{S i O}_{2}$ \\
\hline \multicolumn{10}{|c|}{} \\
\hline 19.3 & 10.4 & 3.54 & 132 & $<0.1$ & $<0.1$ & 138 & 136 & 72.3 & 14.4 \\
\hline
\end{tabular}


Before the acid leaching the column was flushed with synthetic groundwater to extract the soluble phases potentially formed during sampling and storage. By this procedure the rate of percolation could be stabilized and the permeability of the column assessed. The flow rate was adjusted to about 1 PV/day. Then, synthetic groundwater was circulated through the column in a closed circuit. The purpose of this routine was to reach chemical equilibrium between solid phases and synthetic groundwater, and thus approximating the initial equilibrium of the ore/groundwater system before mining, but these experiments are not of direct interest for the understanding of the phenomenology of ISR. (Ben Simon, 2011).

The acid-solution percolation through the column corresponds to the actual ISR operation. The chemistry of the leachates provides the major constraint of the kinetic reactive transport modelling. The column acid-leaching lasted for 12 days.

\subsection{Numerical modelling}

The geochemical modelling was done with the computer code "CHemical Equilibrium of Species and Surfaces" (CHESS) (Van der Lee and De Windt, 2002). The geochemical reactions coupled with transport were modelled with the HYTEC code, developed by Mines-ParisTech (van der Lee, 2003; van der Lee et al., 2003). HYTEC results from the coupling of the geochemical code CHESS with the transport model R2D2 (Lagneau, 2010) in one, two or three dimensions. Geochemistry and transport coupling is achieved in two steps: the flow is first calculated at each time step, then the geochemical equilibrium is calculated and chemical transport is iteratively computed. This means that after each geochemical change resulting in a variation of porosity/permeability in the system, the code recalculates transport feedback and consecutive geochemistry, and so on until it reaches numerical convergence (Lagneau and van der Lee, 2010).

\subsubsection{Kinetic-rate laws}

Kinetic-rate laws are used to describe the rate at which the different minerals in the ore dissolve or newly formed minerals precipitate during the tests. The computer code CHESS uses rate laws of the general form:

$$
\frac{d[M]}{d t}=k \cdot A_{v} \cdot \prod_{i}\left(A_{i}\right)^{\alpha_{i}} \cdot\left(\left(\frac{Q}{K_{s}}\right)^{p}-1\right)
$$

where $[M]$ (mol/L solution) is the time rate of change in the mole number of the mineral, $k$ is its intrinsic rate constant $\left(\mathrm{mol} / \mathrm{m}^{2} \mathrm{sec}\right)$ at the temperature of the experiment and $A_{v}\left(\mathrm{~m}^{2} / \mathrm{L}\right)$ is the mineral surface area per volume of solution, with $A_{v}=A_{s}[\mathrm{M}], A_{s}$ being the mineral specific surface area $\left(\mathrm{m}^{2} / \mathrm{mol}\right)$. The final grouping $\left(\left(Q / K_{s}\right)^{p}-1\right)$ represents the thermodynamic drive for the reaction through the saturation 
index $\left(Q / K_{s}\right)$ : when the mineral is supersaturated, $Q>K_{s}$ and the mineral precipitates. When it is undersaturated $Q<K_{s}$, it dissolves. Exponent $p$ is the 'order' of the rate law and defines its nonlinearity. The intermediate grouping $\Pi\left(A_{i}\right)^{a i}$ represents the role of other dissolved species in catalyzing or inhibiting the reaction, where exponent $a_{i}$ is positive in the first case, and negative in the laster.

\subsubsection{Modelling philosophy}

A geochemical model taking into account the kinetics requires that the different kinetic parameters be determined or that published values of these parameters be used. Kinetic parameters are highly dependent on experimental conditions ( $\mathrm{pH}$, granulometry, crystallinity, reactive surface area, etc.), and several values may be available for a single mineral. For consistency, and for all but one mineral, the kinetic rate constant $k$ extracted from literature was included in the geochemical models without modification, and never modified in the subsequent modellings. The simulation results were fitted on the experimental data by adjusting the specific surface area $\left(A_{s}\right)$ rather than the kinetic rate. Indeed, the kinetic rate is an intrinsic parameter of a mineral framework; its variations are mainly due to crystallinity/structural defects and specific surface. We chose to keep the same value of the kinetic rates, for batch and column experiment modelling, and to adjust the rate laws by changing the specific/reactive surface area. The reactive surface areas were calibrated on batch experiments but had to be reduced for column simulations to fit experimental data. This decrease is consistent with the test protocols: in batches the solid is shaken and mineral surfaces "activated" by grain collisions, whereas in columns the solid is compacted and thus the contact surfaces between solid and solution are comparatively reduced. In addition, secondary precipitations may also occur at the surface of the primary minerals, thus further reducing their reactive surfaces.

The input parameters used for modelling the leaching tests are listed in Table 4. The natural variability of geochemical parameters is a major limitation of the modelling. Here the very fast reactions were considered at thermodynamic equilibrium and kinetic parameters were applied to the slower reactions. 
Table 4: List and origin of the input parameters used for numerical simulations.

\begin{tabular}{|l|c|}
\hline \multicolumn{2}{|c|}{ GEOCHEMICAL PARAMETERS } \\
\hline \multicolumn{1}{|c|}{ parameters } & provided by \\
\hline solid initial composition & $\begin{array}{c}\text { initial adjustment } \\
\text { XRD \& chemical analysis }\end{array}$ \\
\hline solution output & chemical analysis \\
\hline catalysis / inhibition & literature \\
\hline solubility constants & LLNL v8.06 \\
\hline kinetic constants & literature \\
\hline reactive surface area & modelling \\
\hline
\end{tabular}

\begin{tabular}{|c|c|}
\hline \multicolumn{2}{|c|}{ TRANSPORT PARAMETERS } \\
\hline parameters & provided by \\
\hline Darcy velocity & experimental measurement \\
\hline total porosity & experimental measurement \\
\hline efficient porosity & $\begin{array}{c}\text { calculation from } \\
\text { experimental measurement }\end{array}$ \\
\hline hydraulic conductivity & $\begin{array}{c}\text { calculation from } \\
\text { experimental measurement }\end{array}$ \\
\hline dispersivity & literature \\
\hline storage coefficient & literature \\
\hline
\end{tabular}

\subsubsection{Conceptual model of the experimental reactions}

A deductive conceptual model for the acid leaching was constructed from the column experiments. The basic principle of this is that dissolution is controlled by the progress of the acid front and therefore by the $\mathrm{pH}$ of the leachate. Column-leaching shows five successive stages (Fig. 2): (stage 0 ) latent period of renewal of the interstitial solution, i.e. lasting some 24 hours corresponding to a flow rate of one PV per day; (stage 1) very fast carbonate dissolution which buffers the $\mathrm{pH}$ and may cause precipitation of secondary minerals; (stage 2) relatively fast dissolution of uraninite, iron oxides and pyrite when the $\mathrm{pH}$ drops to near input values; (stage 3) a slower dissolution of uraninite, and (stage 4) a slow dissolution of aluminosilicates.

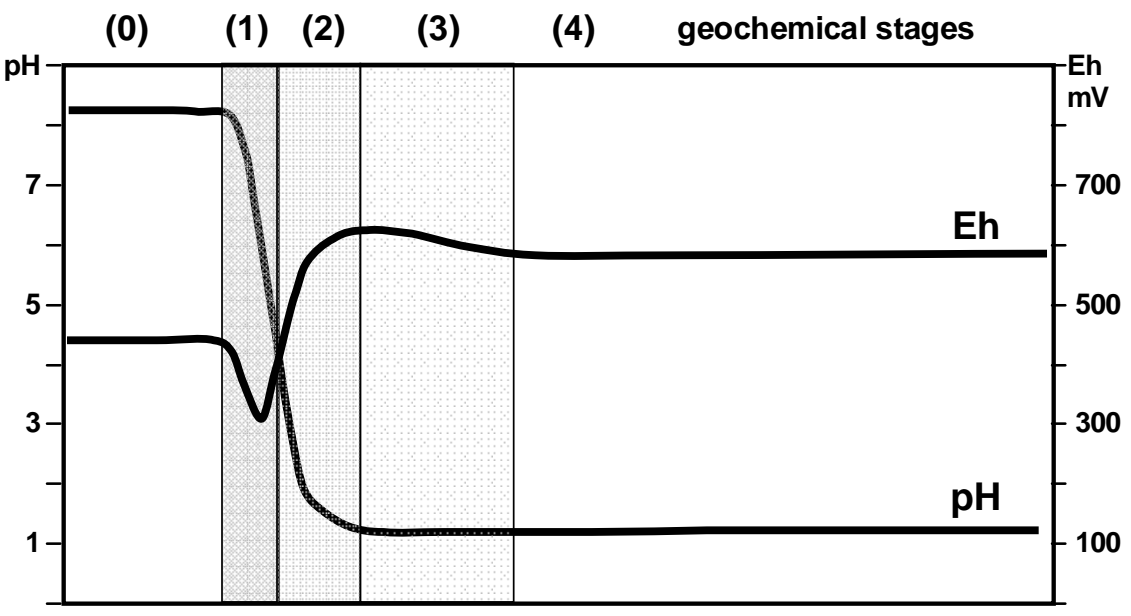

Figure 2: Diagram of the variations of $\mathrm{pH}$ and Eh of column leachates during acid leaching of the columns. 


\subsubsection{Minerals and kinetics}

The mineral species, their formula and solubility constant taken from LLNL database and their kinetic parameters extracted from the literature (based on experimental conditions similar to those of the leaching tests), are summarized in Table 5.

Table 5: Chemical and kinetic parameters used for numerical modelling. Minerals for which no kinetic parameter is specified were considered to precipitate or to dissolve relatively quickly and no kinetic law was applied to them.

\begin{tabular}{|c|c|c|c|c|c|c|}
\hline \multicolumn{2}{|c|}{ minerals } & \multirow{3}{*}{$\begin{array}{c}\text { solubility } \\
\text { Log Ks }\end{array}$} & \multicolumn{4}{|c|}{ kinetic parameters } \\
\hline & & & \multicolumn{2}{|c|}{ dissolution } & precipitation & \multirow{2}{*}{ references } \\
\hline & & & $k\left(\mathrm{~mol} / \mathrm{cm}^{2} / \mathrm{s}\right)$ & cat./inh. & $k\left(\mathrm{~mol} / \mathrm{cm}^{2} / \mathrm{s}\right)$ & \\
\hline uraninite & $\mathrm{UO}_{2}$ & -4.8372 & $3.5 .10^{-12}$ & $\left(\mathrm{H}^{+}\right)^{0.37}\left(\mathrm{O}_{2}\right)^{0.31}$ & - & Torrero et al., 1997 \\
\hline schoepite & $\mathrm{UO}_{3} \cdot 2 \mathrm{H}_{2} \mathrm{O}$ & 4.8333 & $3.5 .10^{-12}$ & $\left(\mathrm{H}^{+}\right)^{0.37}\left(\mathrm{O}_{2}\right)^{0.31}$ & - & set similar to uraninite \\
\hline calcite & $\mathrm{CaCO}_{3}$ & 1.8487 & $1.10^{-5}$ & $\left(\mathrm{H}^{+}\right)^{1}$ & - & \multirow{2}{*}{$\begin{array}{l}\text { Plummer and Busenberg, } \\
1982\end{array}$} \\
\hline dolomite & $\mathrm{CaMg}\left(\mathrm{CO}_{3}\right)_{2}$ & 2.5135 & $1.10^{-7,19}$ & $\left(\mathrm{H}^{+}\right)^{0.5}$ & - & \\
\hline pyrite & $\mathrm{FeS}_{2}$ & -24.6534 & $3.10^{-12}$ & $\left(\mathrm{Fe}^{3+}\right)^{0.58}\left(\mathrm{H}^{+}\right)^{-0.5}$ & - & $\begin{array}{c}\text { McKibben and Barnes, } \\
1986\end{array}$ \\
\hline hematite_1 & $\mathrm{Fe}_{2} \mathrm{O}_{3}$ & 0.1086 & $8.3 .10^{-13}$ & $\left(\mathrm{H}^{+}\right)^{0.5}$ & - & Majima et al., 1985 \\
\hline hematite_2 & $\mathrm{Fe}_{2} \mathrm{O}_{3}$ & 0.1086 & - & - & - & no kinetic \\
\hline albite & $\mathrm{NaAlSi}_{3} \mathrm{O}_{8}$ & -2.7645 & $1.10^{-13,87}$ & $\left(\mathrm{H}^{+}\right)^{0.457}$ & - & \multirow{3}{*}{ Palandri and Kharaka, 2004} \\
\hline microcline & $\mathrm{KAISi}_{3} \mathrm{O}_{8}$ & -0.2753 & $1.10^{-14,06}$ & $\left(\mathrm{H}^{+}\right)^{0.5}$ & - & \\
\hline muscovite & $\mathrm{KAl}_{3} \mathrm{O}_{10} \mathrm{Si}_{3}(\mathrm{OH})_{2}$ & 13.5858 & $1.10^{-15,85}$ & $\left(\mathrm{H}^{+}\right)^{0.37}$ & - & \\
\hline kaolinite & $\mathrm{Al}_{2} \mathrm{Si}_{2} \mathrm{O}_{5}(\mathrm{OH})_{4}$ & 6.8101 & $1.10^{-15,31}$ & $\left(\mathrm{H}^{+}\right)^{0.777}$ & $1.10^{-16.31}$ & Xu et al., 2004 \\
\hline quartz & $\mathrm{SiO}_{2}$ & -3.9993 & $2.10^{-18}$ & - & - & Palandri and Kharaka, 2004 \\
\hline jarosite & $\mathrm{KFe}_{3}\left(\mathrm{SO}_{4}\right)_{2}(\mathrm{OH})_{6}$ & -9.3706 & $3.10^{-13}$ & - & - & \multirow{2}{*}{ Gasharova et al., 2005} \\
\hline alunite & $\mathrm{KAl}_{3}\left(\mathrm{SO}_{4}\right)_{2}(\mathrm{OH})_{6}$ & -0.3479 & $3.10^{-13}$ & - & - & \\
\hline gypsum & $\mathrm{CaSO}_{4} \cdot 2 \mathrm{H}_{2} \mathrm{O}$ & -4.4823 & $6.10^{-9}$ & - & - & Raines et Dewers, 1997 \\
\hline mirabilite & $\mathrm{Na}_{2} \mathrm{SO}_{4} \cdot 10 \mathrm{H}_{2} \mathrm{O}$ & -1.1398 & - & - & - & \multirow{4}{*}{ no kinetic } \\
\hline halite & $\mathrm{NaCl}$ & 1.5855 & - & - & - & \\
\hline sylvite & $\mathrm{KCl}$ & 0.8459 & - & - & - & \\
\hline $\mathrm{SiO}_{2}$ (am) & $\mathrm{SiO}_{2}$ & -2.7136 & - & - & - & \\
\hline
\end{tabular}

The primary minerals initially present in the ore (uraninite, calcite, dolomite, hematite, pyrite, albite, potassium feldspar, muscovite and quartz) were considered to be kinetically controlled for precipitation and dissolution.

Salts formed during the drying of samples were determined from the molar ratios observed in the leachates. Halite $(\mathrm{NaCl})$, sylvite $(\mathrm{KCl})$ and $\left(\mathrm{Na}_{2} \mathrm{SO}_{4} \cdot 10 \mathrm{H}_{2} \mathrm{O}\right)$ were assumed. Given the high speed of their release in solution, we did not introduce kinetic laws for the dissolution of these salts considered as instantaneous.

Uraninite and pyrite oxidation products were based on a literature review (Jambor, 1994; Bigham and Nordstrom, 2000, Hu et al. 2006; Deditius et al. 2007). Schoepite is considered to be the most common oxidation product of uraninite (Deditius et al., 2007). As no kinetics of schoepite dissolution in acidic solution was found in the literature, we applied to it a kinetic law similar to that of uraninite. The oxidation of pyrite in contact with aluminosilicates commonly forms hematite, alunite and gypsum (Hu et al., 2006, Jambor, 1994; Bigham and Nordstrom, 2000). 
Pyrite oxidation in acidic conditions generally results in formation of ferrihydrite. The solubility of ferrihydrite is less well established and is highly dependent on the crystallinity of the mineral (Yu et al., 2002; Stefansson, 2007). For this reason, and in order to simplify the model in view of future fieldscale modelling, we chose not to introduce an additional mineral species into the model, but to consider that the iron-oxides formed by oxidation of pyrite were hematite of very low crystallinity. This oxide is referred to as hematite_2 in order to differentiate it from primary hematite of the deposit which is referred to as hematite_1. With regard to its low crystallinity, hematite_2 was considered at thermodynamic equilibrium (instantaneous dissolution and precipitation).

Neogenic sulphates are the major secondary minerals known to form during the ISR process, and also to significantly affect porosity because of their relatively high molar volumes. Gypsum and alunite are the only sulphate phases present in commonly available thermodynamic data bases and whose precipitation is foreseen by geochemical modelling. Field data confirm the precipitation of gypsum but not that of alunite; other poorly crystallized and yet unidentified Al-bearing hydroxysulphate products were observed instead. Nevertheless alunite was retained in the modelling as a proxy for these phases. Their precipitation is regarded as fairly rapid compared to other aluminium-bearing minerals and in our model, alunite precipitation was considered instantaneous although with kinetically controlled dissolution. Gypsum precipitation was also considered at thermodynamic equilibrium, and its dissolution kinetically controlled.

Clay minerals and amorphous silica are likely to control silica concentration in the leachates. Clay minerals may dissolve and precipitate during the acid leaching because of their saturation state in the leachate. Clay minerals of the host series are mainly composed of illite, interstratified illite-smectite and smectite. In order to simplify the model in view of future modelling developments, we chose to consider only a single phyllosicate species, the muscovite, and to apply to it high specific surface values, until values comparable to those of smectites and even interstratified smectitic minerals (up to $180 \mathrm{~m}^{2} / \mathrm{g}$ ). Nevertheless, kaolinite may form during leaching and its dissolution and precipitation were considered to be kinetically controlled. $\mathrm{SiO}_{2(\mathrm{am})}$ precipitation and dissolution reactions were considered at thermodynamic equilibrium.

Uraninite dissolution kinetics was taken from Torrero et al. (1997):

$$
d[M] / d t=k \cdot A_{s} \cdot[M] \cdot\left(H^{+}\right)^{0,37} \cdot\left(O_{2}\right)^{0,31} \cdot((Q / K s) p-1), \text { with } k=3,5 \cdot 10^{-12} \mathrm{~mol}^{\prime} \cdot \mathrm{cm}^{-2} \cdot \mathrm{s}^{-1}
$$

This law established for a synthetic uraninite and for a $\mathrm{pH}$ in the range of 3 to 6.7 , could not model the batch tests in a satisfactory way. Even by applying a very high reactive surface area $\left(900 \mathrm{~m}^{2} / \mathrm{g}\right)$ and imposing an oxygen fugacity at equilibrium with the atmosphere $(0.2)$ for the duration of the simulation, it was not possible to simulate enough $U$ dissolution to fit the experiments. We simplified the law of uraninite dissolution by removing the oxygen dependence, and by exceptionally adjusting the rate constant $k$ to fit the uranium dissolution in the batch experiments: 


$$
\mathrm{d}[\mathrm{M}] / \mathrm{dt}=\mathrm{k} \cdot \mathrm{A}_{\mathrm{s}} \cdot[\mathrm{M}] \cdot\left(\mathrm{H}_{+}\right)^{0,37} \cdot\left((\mathrm{Q} / \mathrm{Ks})^{\mathrm{p}}-1\right) \text {, with } k=3,5 \cdot 10^{-12} \mathrm{~mol} \cdot \mathrm{cm}^{-2} \cdot \mathrm{s}^{-1}
$$

Mineralogical composition of the simulated sample was based on the XRD quantitative estimate, adjusted to the chemical analysis and the calibration of the batch test modelling. In particular, some uranium dissolved during the flushing of the columns with synthetic groundwater. This early release was considered to be schoepite dissolution and thus schoepite was no longer considered in afterwards simulations (Table 6).

Table 6: Initial input characteristics of the hydrogeochemical model.

\begin{tabular}{|l|l|l|}
\hline \multicolumn{3}{|c|}{ transport parameters } \\
\begin{tabular}{|l|l|l|}
\hline Darcy velocity $\left(\mathrm{V}_{\mathrm{D}}\right) \mathbf{~ c m} /$ day & - & 15 \\
\hline effective porosity $\left(\mathbf{w}_{\text {eff }}\right)$ & - & 0.28 \\
\hline hydraulic conductivity $(\mathrm{K}) \mathbf{~ m} / \mathbf{s}$ & - & $8.10-6$ \\
\hline dispersivity $\left(\mathrm{D}_{\mathrm{L}}\right) \mathbf{m}$ & - & $1.10^{-2}$ \\
\hline solution/solid ratio & $\mathrm{L} / \mathrm{S}=4$ & $\mathrm{PV}=31.4 \%$ \\
\hline
\end{tabular}
\end{tabular}

\begin{tabular}{|c|c|c|c|c|}
\hline \multicolumn{3}{|c|}{ geochemical parameters } & $\begin{array}{c}\text { batches } \\
\text { CHESS }\end{array}$ & $\begin{array}{c}\text { column } \\
\text { HYTEC }\end{array}$ \\
\hline \multicolumn{2}{|c|}{ minerals } & $\%$ & \multicolumn{2}{|c|}{$\mathrm{g} / \mathrm{L}$ of solution } \\
\hline uraninite & $\mathrm{UO}_{2}$ & 0.057 & 0.142 & 2.98 \\
\hline schoepite & $\mathrm{UO}_{3} \cdot 2 \mathrm{H}_{2} \mathrm{O}$ & 0.007 & 0.018 & - \\
\hline calcite & $\mathrm{CaCO}_{3}$ & 0.096 & 0.240 & 5.04 \\
\hline dolomite & $\mathrm{CaMg}\left(\mathrm{CO}_{3}\right)_{2}$ & 0.114 & 0.285 & 5.99 \\
\hline pyrite & $\mathrm{FeS}_{2}$ & 0.870 & 2.000 & 46.00 \\
\hline hematite_1 & $\mathrm{Fe}_{2} \mathrm{O}_{3}$ & 0.025 & 0.063 & 1.31 \\
\hline hematite_2 & $\mathrm{Fe}_{2} \mathrm{O}_{3}$ & 0.025 & 0.063 & 1.31 \\
\hline albite & $\mathrm{NaAISi}_{3} \mathrm{O}_{8}$ & 0.710 & 2.00 & 38 \\
\hline microcline & $\mathrm{KAISi}_{3} \mathrm{O}_{8}$ & 3.52 & 9.00 & 185 \\
\hline muscovite & $\mathrm{KAl}_{3} \mathrm{O}_{10} \mathrm{Si}_{3}(\mathrm{OH})_{2}$ & 1.680 & 4.00 & 88 \\
\hline quartz & $\mathrm{SiO}_{2}$ & 93 & 232 & 4872 \\
\hline alunite & $\mathrm{KAl}_{3}\left(\mathrm{SO}_{4}\right)_{2}(\mathrm{OH})_{6}$ & 0.034 & 0.085 & 1.79 \\
\hline mirabilite & $\mathrm{Na}_{2} \mathrm{SO}_{4} \cdot 10 \mathrm{H}_{2} \mathrm{O}$ & 0.068 & 0.170 & - \\
\hline halite & $\mathrm{NaCl}$ & 0.005 & 0.012 & - \\
\hline sylvite & $\mathrm{KCl}$ & 0.004 & 0.010 & - \\
\hline TOTAL & & 100 & 250 & 5252 \\
\hline
\end{tabular}

\subsubsection{Hydrodynamic model}

Column tests were simulated with the reactive transport code HYTEC in its 1D-version. A simplified system was built to represent the column used for experimental tests. The simulated column is a rectangle $50 \mathrm{~cm}$ long and $1 \mathrm{~cm}$ wide, discretized into 100 rectangular meshes of equal length $(0.5 \mathrm{~cm})$. Injection is homogeneous on the input surface (width) of the column. The flow was uniform and constant throughout the simulation. Transport was defined by two boundary conditions (Lagneau, 2000): at the input of the column, the concentrations of elements were prescribed and corrected for dispersion; at the output of the column, the concentration gradient was zero. 
The transport parameters introduced to simulate the percolation of the columns were Darcy velocity $\left(V_{D}\right)$, effective porosity $\left(W_{\text {eff }}\right)$, hydraulic conductivity $(K)$ and dispersivity $\left(D_{L}\right)$. The molecular diffusion coefficient was neglected.

The percolation rate $\left(Q_{P}\right)$ of the fluid within the column was prescribed through a constant Darcy velocity $\left(V_{D}\right)$ and calculated from the mean flow measured during the column tests. The effective porosity was adjusted during the simulation of the column tests to reproduce the beginning of acidification of the column. The hydraulic conductivity $(\mathrm{K})$ of the column was calculated from measurements of percolation rates $\left(Q_{P}\right)$ and of the pressure drop $(\Delta h)$ during the tests according to Darcy's formula.

The compositions of the solutions (synthetic groundwater and acid solution) were determined by chemical analyses (Table 7).

Table 7: Chemistry of the injection solutions for column test simulations. The recycled plant solution is given for comparison.

\begin{tabular}{|l|lll|l|l|l|l|l|l|l|l|l|}
\hline $\mathrm{TC}$ & $\mathrm{pH}$ & $\mathrm{fO}_{2}$ & $\mathrm{fO}_{2}$ & $\mathrm{HCO}_{3}^{-}$ & $\mathrm{Cl}^{+}$ & $\mathrm{SO}^{2-}$ & $\mathrm{Na}^{+}$ & $\mathrm{K}^{+}$ & $\mathrm{Mg}^{2+}$ & $\mathrm{Ca}^{2+}$ & $\mathrm{SiO}_{2}$ & $\mathrm{Fe}$ \\
\hline \multicolumn{10}{|c|}{$\mathrm{mg} / \mathrm{L}$} \\
\hline
\end{tabular}

\begin{tabular}{|l|c|ccc|c|c|c|c|c|c|c|c|c|}
\hline synthetic groundwater & 25 & 7 & 0.0003 & 0.2 & 154 & 125 & 32 & 123 & 8.5 & 6 & 14 & 28 & 0 \\
\hline leaching solution $\left(\mathbf{8 g} / \mathrm{L} \mathrm{H}_{\mathbf{2}} \mathbf{S O}_{4}\right)$ & 25 & 1 & 0.0003 & 0.2 & - & 138 & 7960 & 122 & 2.6 & 9.4 & 32 & 34 & 0.2 \\
\hline recycled plant solution & 25 & 1.1 & 0.0003 & 0.2 & & 70 & 7960 & 130 & 60 & 300 & 531 & 42 & 160 \\
\hline
\end{tabular}

\section{Simulation of leaching tests}

Numerical simulations of the acid leaching tests (batch and column experiments) are shown. Batch test simulations are necessary to constrain and calibrate the geochemical model, but are not representative of the phenomenology occurring during ISR mining operations. Modelling and interpretation of acid leaching of columns are of direct interest and can be compared to an ISR mining operation. Here, the presentation is limited to the tests conducted with a solution of $8 \mathrm{~g} / \mathrm{L} \mathrm{H}_{2} \mathrm{SO}_{4}$. Results of the tests performed with a solution of $15 \mathrm{~g} / \mathrm{L} \mathrm{H}_{2} \mathrm{SO}_{4}$ are detailed in Ben Simon (2011).

\subsection{Geochemical characteristics of the leachates}

Herein it is not possible to give all the analytical results, only synthetic and global results are presented below. Nevertheless, composition of the leachates and calculated mineral saturation indices in the column experiments and those resulting from the modelling are given for the successive geochemical stages defined previously (Tables 8 and 9). There is a general good agreement between experiment and modelling. The pHs that determine the successive geochemical stages are in good accordance. Nevertheless, not all the chemical compositions are available and some discrepancies may also result because it was necessary to blend several 6 hours aliquots together to reach the volume needed for chemical analysis. The saturation indices show that primary minerals may still be in equilibrium and 
some secondary minerals may precipitate almost only during stage 1 , at starting of acid injection, when $\mathrm{pH}$ remains weakly acid. All saturation indices become strongly negative during later stages except for gypsum that remains relatively close to saturation.

Table 8: Comparison of the chemical compositions of the leachates in the column experiments and in the model at the successive geochemical stages (8 $\mathrm{g} / \mathrm{L} \mathrm{H}_{2} \mathrm{SO}_{4}$ leaching tests).

\begin{tabular}{|c|c|c|c|c|c|c|c|c|c|c|c|c|c|}
\hline \multirow{2}{*}{\multicolumn{2}{|c|}{ time (days) }} & \multirow{2}{*}{\multicolumn{2}{|c|}{$\begin{array}{c}\text { STAGE } 1 \\
2.5\end{array}$}} & \multirow{2}{*}{\multicolumn{2}{|c|}{$\begin{array}{c}\text { STAGE } 2 \\
3.5 \\
\end{array}$}} & \multicolumn{4}{|c|}{ STAGE 3} & \multicolumn{4}{|c|}{ STAGE 4} \\
\hline & & & & & & \multicolumn{2}{|c|}{4.0} & \multicolumn{2}{|c|}{5.0} & \multicolumn{2}{|c|}{5.5} & \multicolumn{2}{|c|}{10.0} \\
\hline & & exper. & model & exper. & model & exper. & model & exper. & model & exper. & model & exper. & model \\
\hline \multicolumn{2}{|r|}{ pH } & 4.49 & 4.55 & 1.47 & 1.56 & 1.30 & 1.37 & 1.29 & 1.25 & 1.27 & 1.22 & 1.26 & 1.12 \\
\hline \multicolumn{2}{|r|}{ Eh } & 424 & 114 & 629 & 659 & 615 & 292 & 599 & 293 & 594 & 629 & 589 & 602 \\
\hline \multirow{2}{*}{$\mathrm{Ca}^{2+}$} & $\mathrm{mg} / \mathrm{L}$ & 586 & 585.8 & - & 576.7 & - & 612.7 & - & 637.9 & 223 & 622.5 & 59 & 38.3 \\
\hline & $\mathrm{mmo} / \mathrm{L}^{-}$ & 14.62 & 14.62 & - & 14.39 & - & 15.29 & - & 15.92 & 5.56 & 15.53 & 1.48 & 0.96 \\
\hline \multirow{2}{*}{$\mathrm{Mg}^{2+}$} & $\mathrm{mg} / \mathrm{L}$ & 350 & 138.9 & - & 340.1 & - & 240.0 & - & 110.9 & 40 & 75.0 & 40 & 11.1 \\
\hline & $\mathrm{mmol} / \mathrm{L}^{-}$ & 14.40 & 5.71 & - & 13.99 & - & 9.88 & - & 4.56 & 1.65 & 3.08 & 1.65 & 0.46 \\
\hline \multirow{2}{*}{$\mathrm{Fe}$} & $\mathrm{mg} / \mathrm{L}$ & 456 & 743.3 & - & 474.9 & - & 199.8 & - & 158.2 & 120 & 139.7 & 59.9 & 30.2 \\
\hline & $\mathrm{mmol} / \mathrm{L}^{-}$ & 8.17 & 13.31 & - & 8.50 & - & 3.58 & - & 2.83 & 2.15 & 2.50 & 1.07 & 0.54 \\
\hline \multirow{2}{*}{$\mathbf{U}$} & $\mathrm{mg} / \mathrm{L}$ & 2090 & 1969.41 & - & 875.66 & - & 371.89 & - & 145.46 & 106 & 11.72 & 46.9 & 2.47 \\
\hline & $\mathrm{mmol} / \mathrm{L}^{-}$ & 7.74 & 7.29 & - & 3.24 & - & 1.38 & - & 0.54 & 0.39 & 0.04 & 0.17 & 0.01 \\
\hline \multirow{2}{*}{$\mathrm{SO}_{4}{ }^{2-}$} & $\mathrm{mg} / \mathrm{L}$ & 6730 & 3331 & - & 8155 & - & 8551 & - & 9025 & 11100 & 9104 & 9500 & 7850 \\
\hline & $\mathrm{mmol} / \mathrm{L}^{-}$ & 70.06 & 34.67 & - & 84.90 & - & 89.01 & - & 93.95 & 115.55 & 94.77 & 98.89 & 81.72 \\
\hline \multirow{2}{*}{$\mathrm{Na}^{+}$} & $\mathrm{mg} / \mathrm{L}$ & 207 & 127 & - & 136 & - & 137 & - & 138 & 156 & 138 & 140 & 138 \\
\hline & $\mathrm{mmol} / \mathrm{L}^{-}$ & 9.00 & 5.53 & $=$ & 5.92 & - & 5.95 & - & 5.99 & 6.79 & 6.00 & 6.09 & 6.02 \\
\hline \multirow{2}{*}{ Al } & $\mathrm{mg} / \mathrm{L}$ & 50.3 & 0.2 & - & 177.9 & - & 136.4 & - & 84.7 & 51.7 & 68.7 & 100 & 27.6 \\
\hline & $\mathrm{mmol} / \mathrm{L}$ & 1.86 & 0.01 & - & 6.59 & - & 5.05 & - & 3.14 & 1.92 & 2.55 & 3.71 & 1.02 \\
\hline \multirow{2}{*}{$\mathrm{K}^{+}$} & $\mathrm{mg} / \mathrm{L}$ & 96.8 & 4.9 & - & 84.4 & - & 64.1 & - & 38.9 & 25.1 & 31.1 & 21.5 & 11.2 \\
\hline & $\mathrm{mmo} / \mathrm{L}^{-}$ & 2.48 & 0.13 & - & 2.16 & - & 1.64 & & 0.99 & 0.64 & 0.80 & 0.55 & 0.29 \\
\hline
\end{tabular}

Figure 9: Simulation of the amounts of secondary minerals that precipitate as a function of variations of the mineralogical composition of the ore and the acidity of the leaching solution.

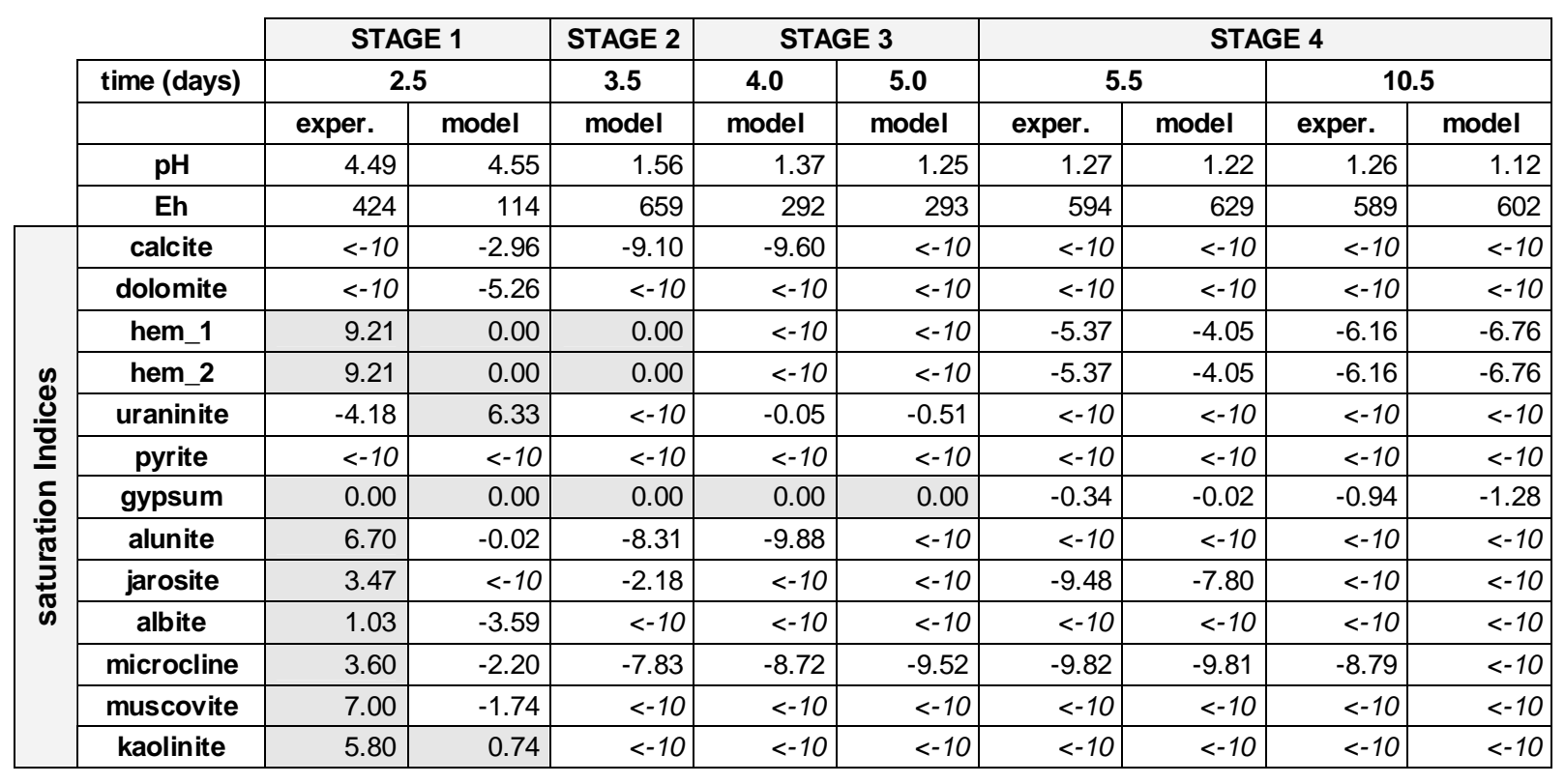




\subsection{Carbonates and pH}

Batch experiments show very fast release of $\mathrm{Ca}$ and $\mathrm{Mg}$ followed by minor increase of these elements (Fig. 3). Carbonate amount had to be adjusted, most probably due to intra-sample variability as carbonate content in the composite sample is $<0.2 \%$.

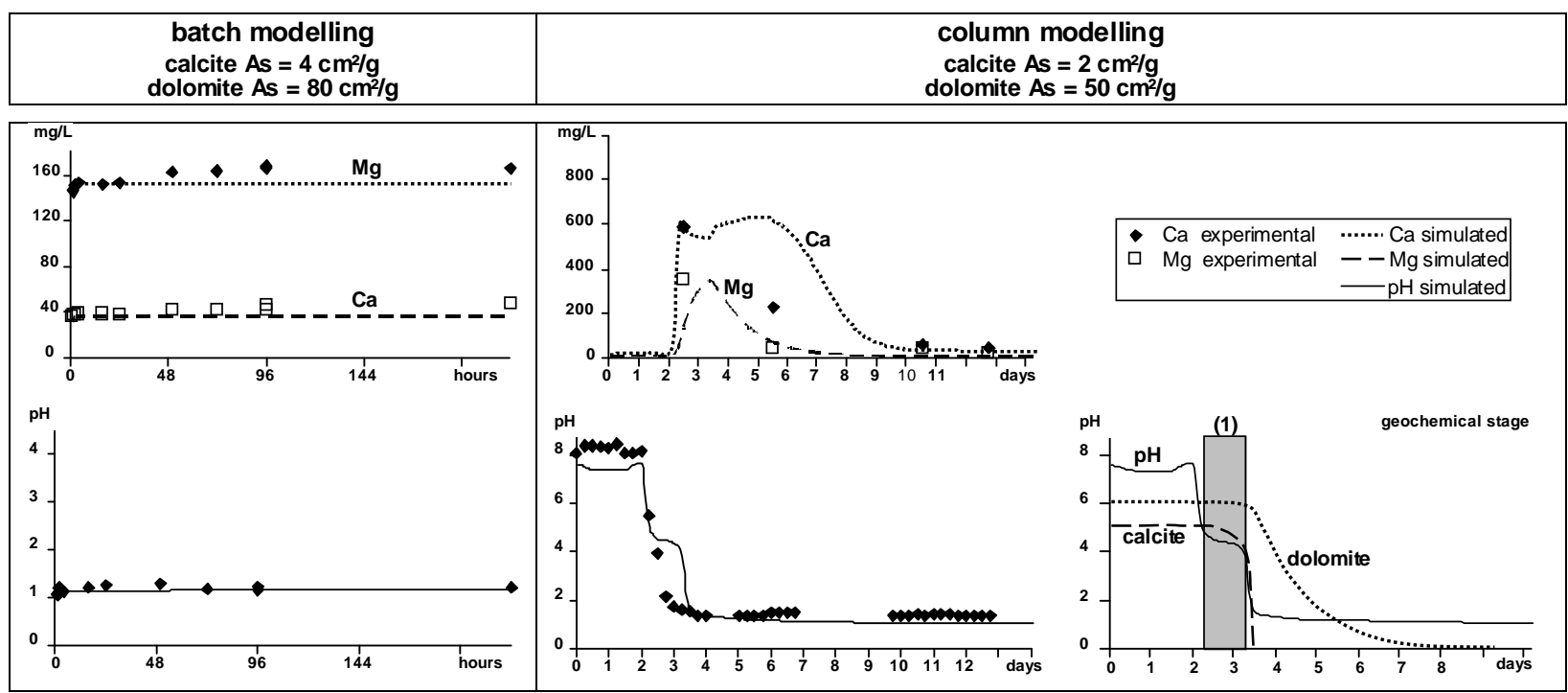

Figure 3: Modelling of the $\mathrm{pH}$ and the behaviour of the carbonates during leaching experiments.

Reactive surface areas were calibrated on batch experiments but had to be divided by almost 2 for column simulations to fit experimental data. However, in column test $\mathrm{Ca}$ and $\mathrm{Mg}$ release spreads out during a relatively long period of time; this is caused by the dissolution of carbonates (calcite and dolomite) linked to the $\mathrm{pH}$ decrease in the early stage of column acidification (Fig. 3 ). The simulation of $\mathrm{Ca}$ and $\mathrm{Mg}$ releases by kinetically-controlled dissolution of carbonates fits well with the experimental data. Nevertheless, the simulation shows that carbonate dissolution (mainly calcite) temporarily buffers $\mathrm{pH}$ around 4.5 (stage 1) wich is not detected on the experimental $\mathrm{pH}$ curve probably due to the spacing of the sampling (6 hrs).

\subsection{Iron oxide behaviour}

Iron shows two stages of release during leaching (Fig. 4A). The batch experiments show an initial iron release, followed by a progressive increase of concentrations. The observations lead to the development of two iron oxide reservoirs: (1) iron oxide of sedimentary/diagenetic origin (2) a highly reactive oxi-hydroxide iron phase produced by atmospheric oxidation of the solid between sampling and the actual experiment. This leads us to introduce two oxi-hydroxide iron phases in our model; (1) hematite_1 with a kinetically constrained dissolution, (2) hematite_2 considered at thermodynamic equilibrium. 


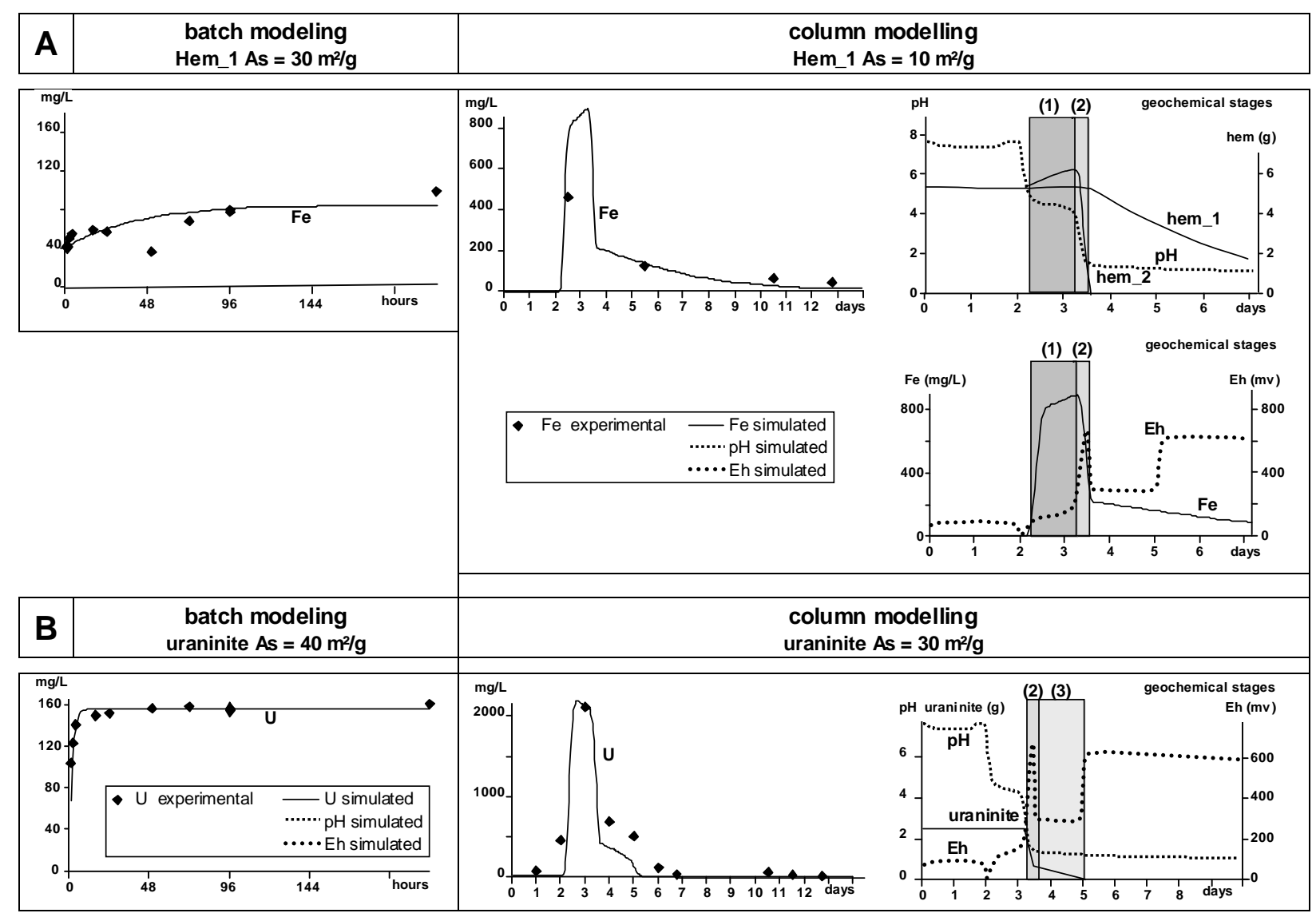

\begin{tabular}{|l|l|l|}
\hline C & batch modelling & column modelling \\
\hline
\end{tabular}

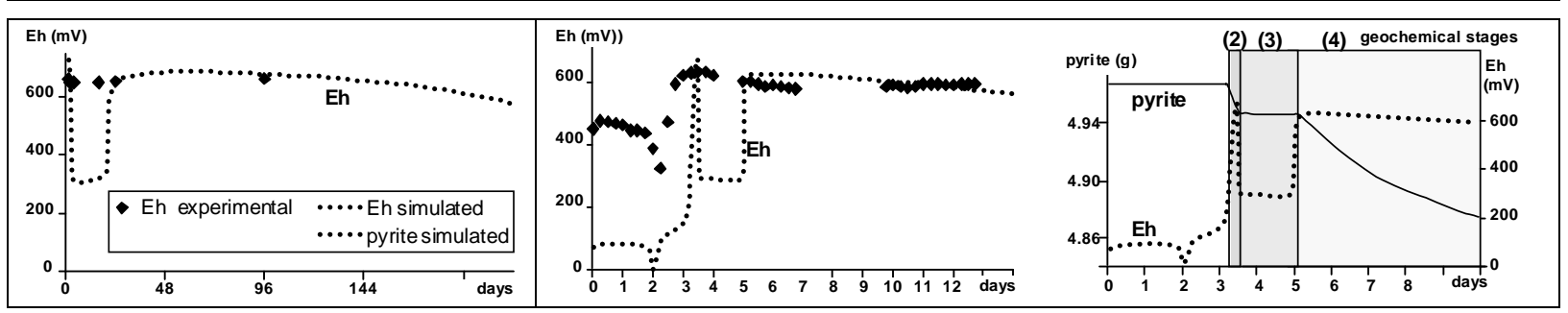

Figure 4: Modelling of redox sensitive minerals. A - Behaviour of iron during leaching experiments. B - U dissolution during leaching experiments. C - Redox potential (Eh) and pyrite dissolution during leaching experiments.

The column experiment steps of iron releases were correctly reproduced considering the 2 iron oxide dissolution behaviour. The hematite amounts were adjusted on experimental batch data: first, the hematite_2 amount was adjusted to fit the rapid initial Fe release; then, hematite_1 was adjusted on the remaining Fe release. The hematite_1 reactive surface area was initially calibrated on batch experiments and had to be divided by a factor of 3 for the column simulation.

The column simulation shows that hematite_2 precipitates during $\mathrm{pH}$ buffering due to carbonate dissolution (stage 1). Then, when the $\mathrm{pH}$ drops (stage 2), the $\mathrm{Fe}^{3+}$ solubility increases, the hematite_2 quickly dissolves; the new buffer redox results in a sharp increase of simulated Eh values (Fig. 4A). 


\subsection{Uranium leaching}

During batch experiments the uranium is released very rapidely, and its maximum concentration is reached within 24 hours (Fig. 4B). During column tests, uranium is released in three steps. A first release occurs during the flushing of the column with water (stage 0 ). It corresponds to the dissolution of the uraninite atmospheric oxidation products (schoepite). Two further uranium releases occur during the acid leaching of the column: (1) a rapid and intense release occurs as soon as the $\mathrm{pH}$ drops (stage 2) and (2) it is followed bya slower and more progressive one (stage 3).

The initial amount of uraninite was adjusted from batch experiment data minus the part of uranium (schoepite) released when the column was rinsed with water (stage 0 ). The uraninite reactive surface area was initially adjusted on batch experiments and had to be slightly reduced for the column simulation.

Uranium releases are simulated by kinetically controlled uraninite dissolution. In column simulation, the first stage of uranium release is caused by high Eh values (stage 2) resulting from hematite_2 dissolution: it is an oxidative dissolution. Once the hematite_2 is fully dissolved, Eh drops (stage 3) due to a poorer Eh buffering by the kinetically controlled hematite_1; oxidative uraninite dissolution continues, controlled by $\mathrm{Fe}^{3+}$ availability, but now with the kinetic control of hematite_1 dissolution, that limits the oxidative rate. Finally, Eh values increase sharply as soon as the uraninite is fully dissolved (stage 4) (Fig. 4B).

\subsection{Sulphur behaviour}

The initial amount of pyrite was adjusted according to the sulphur abundance obtained by chemical analysis. The pyrite reactive surface area was adjusted by batch experiment simulation, and left unchanged for column simulations.

Simulated pyrite dissolution is controlled by the redox values. There are three successive steps (Fig. 4C): first a rapid oxidative dissolution due to high Eh values resulting from hematite_2 dissolution (stage 2), followed by an inhibition of pyrite dissolution caused by low Eh values resulting from lower uraninite oxidative dissolution (stage 3), and finally a slow oxidative dissolution of pyrite following complete uraninite dissolution and resulting in higher Eh values (stage 4).

Simulated redox values do not fit the experimental values very well (Fig. 4C). There are low calculated Eh values, related to uraninite dissolution, which were not observed during the leaching test probably due to re-equilibration of the leachate in contact with the atmosphere.

\subsection{Gypsum and alunite}

The sulphate concentration in leachates is primarily related to the injection of sulphuric acid and partly to the dissolution/precipitation of sulphate minerals such as gypsum and alunite (Fig. 5). 
Gypsum and alunite precipitations are very rapid due to strong oversaturation after the sulphuric acid injection. Therefore they were considered to occur at thermodynamic equilibrium. In contrast, the gypsum and alunite dissolutions are slower and were kinetically controlled in the geochemical model. As no gypsum precipitation occurs during batch experiments, the gypsum reactive surface area was only adjusted for the column simulation. The alunite reactive surface area was first calibrated on batch experiments and then reduced to about half its value to fit the column simulation with experimental data.

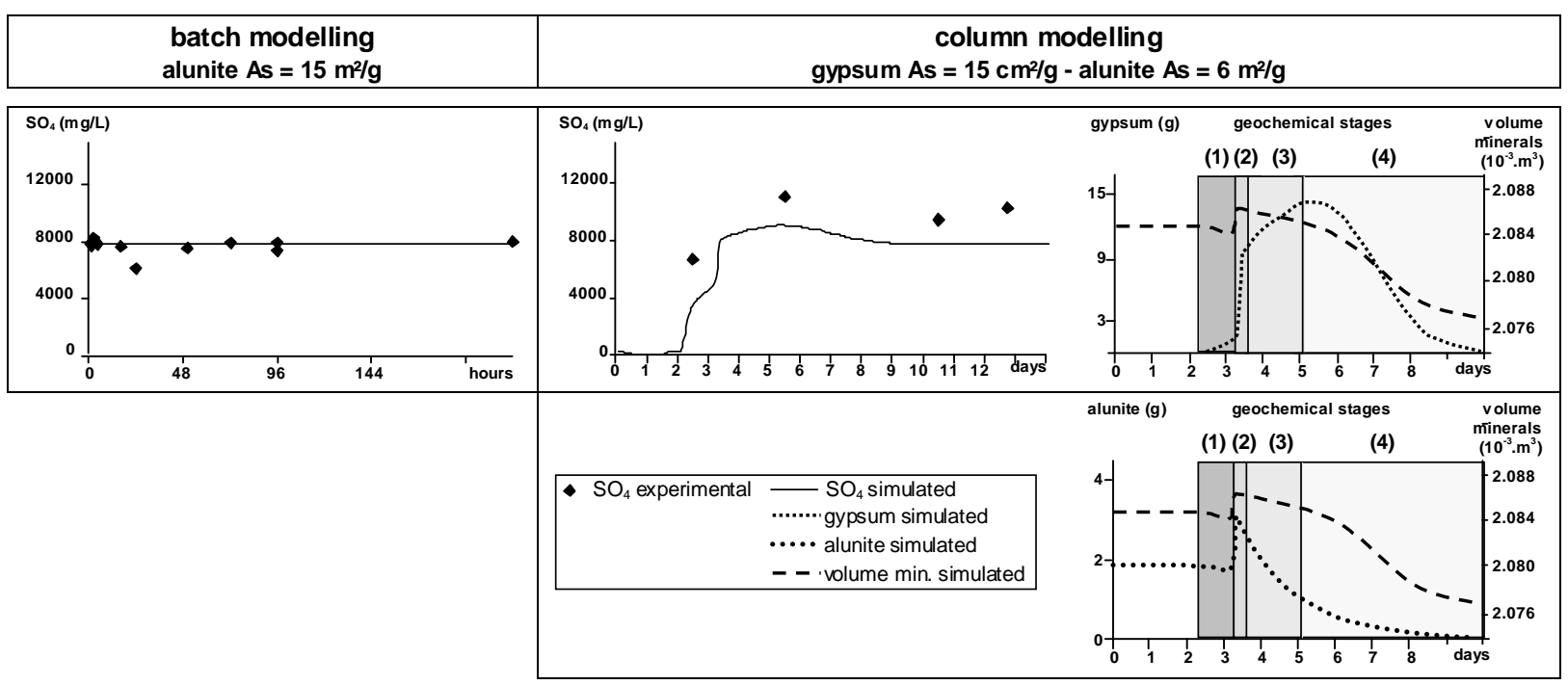

Figure 5: Modelling of sulphates behaviour during leaching experiments.

Sulphate releases in batches are correctly simulated. However, simulated sulphate releases in column leachates are systematically lower than the experimental data, although they show a similar trend (Fig. 5).

In the column simulation, gypsum precipitation is made possible by $\mathrm{Ca}$ release during carbonate dissolution by sulphuric acid (stage 1). Subsequently, alunite precipitates, due to the $\mathrm{pH}$ decrease related to the hematite_2 dissolution (stage 2). Finally, when the pH drops below 3 , alunite dissolves (stage 3), and gypsum begins to dissolve as soon as all carbonates are nearly dissolved (stage 4).

\subsection{Silicates vs alunite}

The leaching experiments show an initially rapid $\mathrm{Al}$ and $\mathrm{K}$ release that was explained by the dissolution of the alunite formed during atmospheric oxidation of the samples (Fig. 6). This initial release is followed by a slower $\mathrm{Al}$ and $\mathrm{K}$ release, which was interpreted as related to the dissolution of aluminosilicates (microcline, albite, muscovite and clay minerals). 


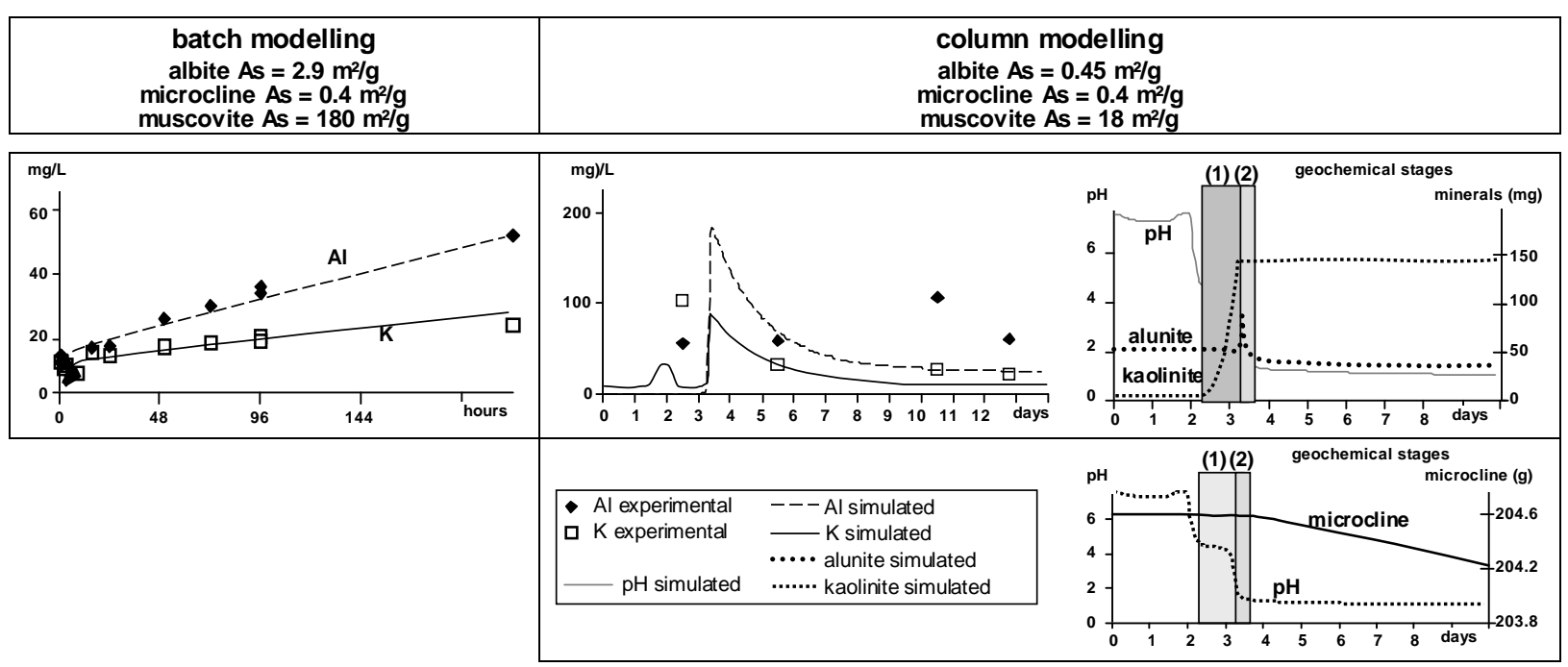

Figure 6: Modelling of $\mathrm{Al}$ and $\mathrm{K}$ release during leaching experiments.

The initial amount of alunite, formed by oxidation during sample storage, was calibrated on the initial releases in batches. The initial amount of albite was computed from the $\mathrm{Na}_{2} \mathrm{O}$ content of the sample. The initial amounts of microcline and muscovite were also computed from $\mathrm{K}_{2} \mathrm{O}$ content with the assumption that $75 \%$ of the potassium is contained in microcline and $25 \%$ in muscovite, based on DRX results.

Silicates are characterized by very slow dissolution kinetics. The reactive surface areas of silicates were adjusted to fit aluminium and potassium dissolution rates in batch experiments. Except for microcline, the reactive surface areas had to be greatly reduced to fit simulation of the column test (Fig. 6).

Kaolinite precipitation is related to alunite and quartz dissolution (stages 2 and 3 ) and stops when the pH drops below 3 (stage 4) (Fig. 6). Silicate dissolution begins when carbonates and iron oxides have been dissolved, allowing $\mathrm{pH}$ to become very acidic $(\mathrm{pH}<3)$.

\subsection{Synthesis}

The main geochemical reactions occurring during the simulated leaching of the column are (Fig. 7): (stage 1) the initial $\mathrm{pH}$ decrease leading to calcite dissolution, which in turn buffers the $\mathrm{pH}$ and provokes precipitation of hematite_2; (stage 2) with continuing pH decrease, hematite_2 is rapidly and fully dissolved, buffering the redox potential and leading to oxidative dissolution of uraninite; (stage 3) then hematite_1 slowly dissolves, Eh declines resulting in acid dissolution of uraninite.

Only very small amounts of minerals $(\sim 5 \%)$ react as compared to the total solid, and the simulation of the acid leaching shows only very little change in the final paragenesis. Nevertheless, the column simulation highlights the strong reactivity of these small amounts of minerals and their great influence on the uranium leaching. In fact, two chemical processes control uranium leaching: fast oxidative dissolution due to $\mathrm{Fe}^{3+}$ release at equilibrium during hematite_2 dissolution (i.e. neoformed iron oxi- 
hydroxide during atmospheric weathering of the sample), then a slower oxidative dissolution controlled by kinetic hematite_1 dissolution. Thus, carbonates as well as silicates may limit uranium recovery efficiency as they buffer the $\mathrm{pH}$ and indirectly limit the solubility of $\mathrm{Fe}^{3+}$, whereas iron oxides in the ore will release $\mathrm{Fe}^{3+}$ which in turn increase the $\mathrm{Eh}$, and thus favour uranium leaching.

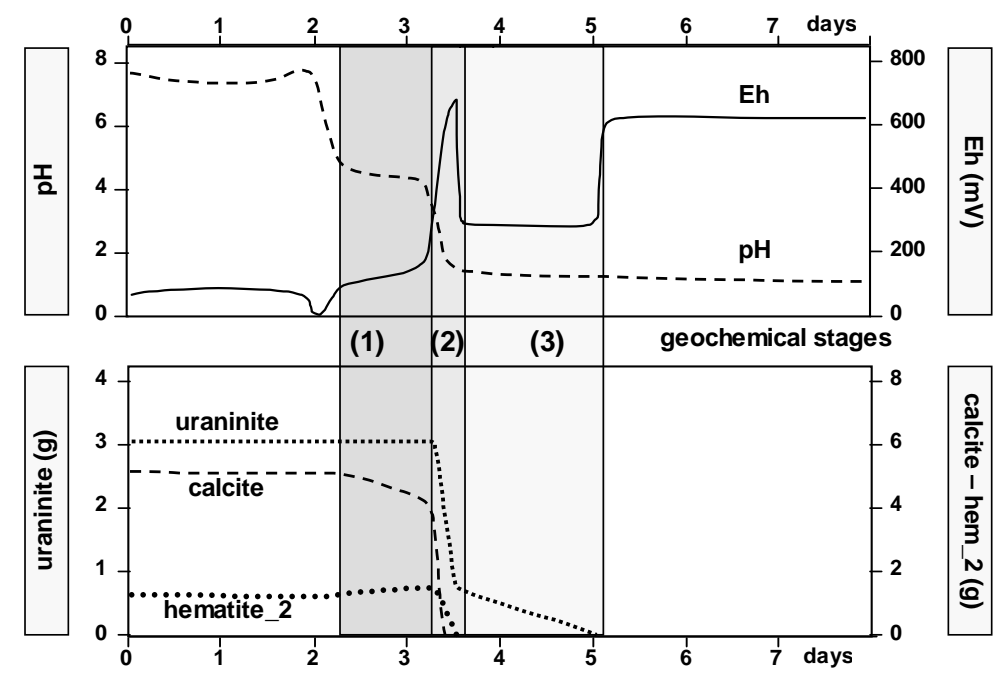

Figure 7: Synthesis of the successive geochemical stages that appear in the numerical simulation of the column leaching experiments.

\section{Sensitivity analysis}

A sensitivity study was carried out on the column model to determine how uranium recovery is influenced by the composition of the acid leaching solution, by the mineralogical composition of the ore and by the flow rate between injection and recovery wells.

The acidity of the leaching solution was simulated with $\mathrm{H}_{2} \mathrm{SO}_{4}$ concentrations of 8 and $15 \mathrm{~g} / \mathrm{L}$, in order to determine its influence on the efficiency of the leaching process. However, the chemical composition of the leaching solution used in the mining operation differs from that of the acid solution used in the laboratory tests. The raison is that ISR mining operates in a "closed circuit": after the uranium extraction, the leaching solution is again acidified and re-injected into the ore. Thus, the acidic solution already contains $\mathrm{Ca}, \mathrm{Al}, \mathrm{Fe}$ and $\mathrm{SO}_{4}$, which may affect dissolution and precipitation reactions.

Sensitive minerals, which have a $\mathrm{pH}$ - or a redox-buffering capacity, impact uranium recovery. Besides, oxidation and $\mathrm{pH}$ are related through the $\mathrm{pH}$-dependency on $\mathrm{Fe}^{3+}$ concentration. The role of two groups of minerals was tested by changing their amounts in the simulated-rock composition: (1) carbonates (calcite and dolomite) -and to a lesser extent silicates- that have a buffering effect on the $\mathrm{pH}$; (2) iron oxides (hematite_1 and hematite_2) and pyrite that have a redox buffering effect.

Pore velocity (or flow rate) of the solution also influences uranium recovery. Whatever the reaction kinetics, the flow rate has always an effect on the solution concentration, and thus affects dissolution/precipitation reactions. At a constant injection rate, the effective porosity modifies the pore velocity and the residence time. Three porosity values were tested: (1) the effective porosity of $28 \%$ in 
the initial column experiment; (2) a simulated porosity of $14 \%$ corresponding to twice the pore velocity of the experimental value; (3) a simulated porosity of twice the value (56\%), which is unrealistic but corresponds to half the pore velocity in the experiment.

\subsection{Effect on leachate volume and acid consumption}

Leaching simulations with varied acid concentrations were conducted by changing the input parameters one by one to ascertain the influence of each one. Three assessment criteria were set:

- The amount of percolated leaching solution (cumulative L/S), corresponding to the amount of solution to be treated in the mining plant;

- The amount of acid consumption in $\mathrm{kg}$ of $\mathrm{H}_{2} \mathrm{SO}_{4}$ per ton of ore, calculated by the mass balance of protons in the injected and in the output solutions;

- The effect of secondary mineral precipitation on effective porosity.

The sensitivity of the uranium recovery versus the variation of an input parameter is evaluated for a uranium recovery of $85 \%$, which corresponds to the operator's target. The effects of changing input parameters were evaluated with regard to the relative variation of the criteria versus the conditions of the initial leaching simulation constrained by the column experiments (Fig. 8).

Acid consumption increases with:

- increasing carbonate content in the sample which is the factor most sensitive to acid consumption;

- decreasing pore velocity, low percolation rates promoting kinetically controlled reactions and acid consumption, especially silicate dissolution;

- increasing acidity of the leaching solution $\left(15 \mathrm{~g} / \mathrm{L}\right.$ instead $8 \mathrm{~g} / \mathrm{L}$ of $\left.\mathrm{H}_{2} \mathrm{SO}_{4}\right)$ due to higher silicate dissolution.

Leachate volumes that have to be treated increase with:

- increasing carbonate content in the ore;

- decreasing iron oxide content, especially when leaching is operated with a less acidic solution (8 $\mathrm{g} / \mathrm{L}$ of $\mathrm{H}_{2} \mathrm{SO}_{4}$ );

- decreasing pore velocity, whereas leachate volumes decrease slightly with increasing flow rate; In general, simulation with the recycled plant solution shows only little changes. The acid consumption and the leachate volume to be treated are slightly reduced when the plant solution is used, due to its higher $\mathrm{Fe}^{3+}$ content. Besides, the comparison between the simulations with $8 \mathrm{~g} / \mathrm{L}$ and $15 \mathrm{~g} / \mathrm{L} \mathrm{of} \mathrm{H}_{2} \mathrm{SO}_{4}$ shows that if in the case of leaching with a solution of $15 \mathrm{~g} / \mathrm{L}$ the amount of leaching solution to be treated decreases, whereas the acid consumption increases, mainly because of a stronger attack of silicate minerals. 


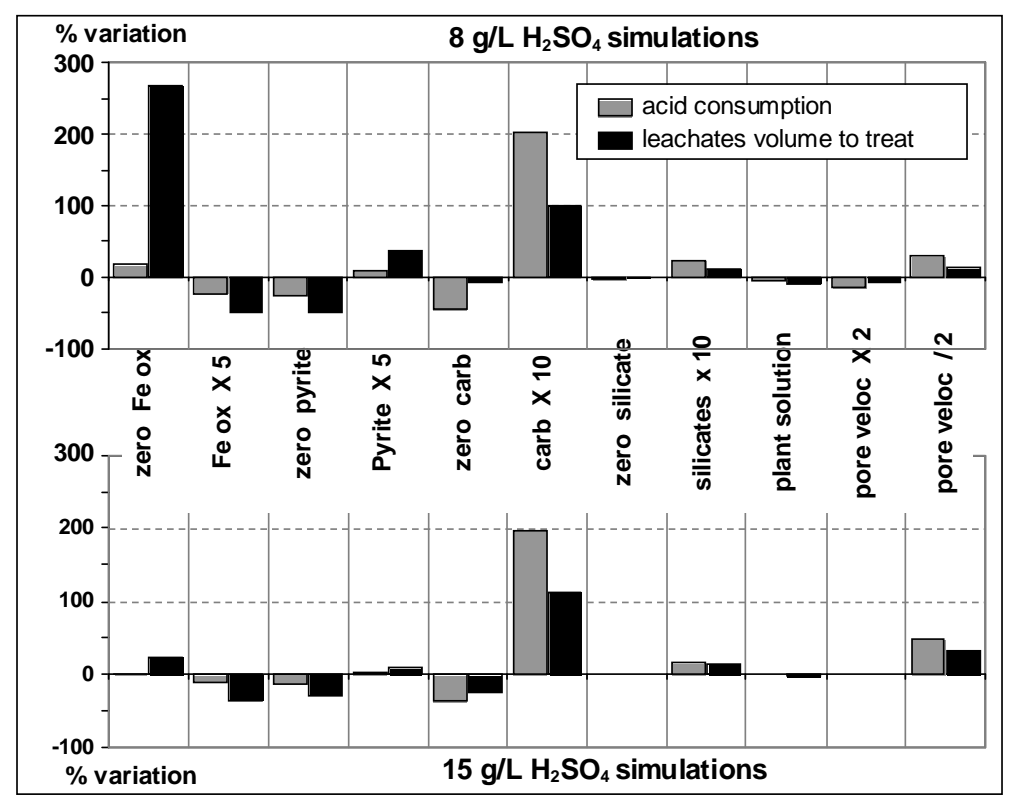

Figure 8: Results of simulation tests for uranium recovery of $85 \%$.

In abscissa, the models tested: 'zero Feox' and 'Feox $x$ ' ' correspond respectively to the model without iron oxides (hematite_1 and hematite_2) and the model with a quantity of iron oxide multiplied by 5 compared to the initial model. 'zero pyrite' and 'pyrite $\times 5$ ' correspond to the model without pyrite and the model with a quantity of pyrite multiplied by 5. ' zero carb' and 'carb x 10' correspond to the model without the carbonates and with a ten-fold carbonate increase.

'zero silicate' and 'silicates $\times 10$ ' correspond to the model without aluminosilicates and with a tenfold increase of aluminosilicates. 'pore veloc X2' and 'pore veloc/2' correspond to models for which the pore velocity of the initial model was respectively multiplied and divided by 2 . The model plant solution tested a solution injection comparable to that of a real ISR mining operation.

\subsection{Effect of secondary minerals}

The mineralogical composition of the ore directly affects acid consumption and the volume of leachate that has to be treated. It also influences the precipitation of secondary minerals which in turn may clog the porosity and affect leaching efficiency. Simulations show that (Fig. 9):

- higher initial content of carbonate and iron oxide increases alunite precipitation. Carbonate and iron oxide dissolutions are acid consuming and buffer the $\mathrm{pH}$ which in turn favours alunite precipitation (Fig. 9A and 9B);

- higher acidity of the leachate increases the amount of precipitating gypsum, because more sulphate is available in solution; but it also diminishes alunite precipitation which becomes unstable in very low pH (Fig. 9C and 9D);

- increasing carbonate content always increases precipitation of secondary minerals (alunite, gypsum and kaolinite) (Fig. 9A, 9E and 9F);

- larger amounts of silicates (feldspars and mica) in the ore induce more kaolinite precipitation (Fig. 9F).

In all simulated cases, the change in precipitated mineral volumes remains very low $(<2 \%)$ and always follows the same trend: (1) volume increase at the beginning of the leaching, related mainly to the 
precipitation of alunite and gypsum, followed by (2) a gradual decrease in mineral volume as the secondary minerals are dissolved.

It is not easy to control or correct the mineral volume increase: if the acidity of the leaching solution is increased, alunite precipitation decreses, but gypsum precipitation correlatively increases. Acidity increase is only effective in the case of a carbonate-free ore. In the case of carbonate-bearing ores, it is more advantageous to use a less acidic leaching solution, at least in the early stages of a mining operation.
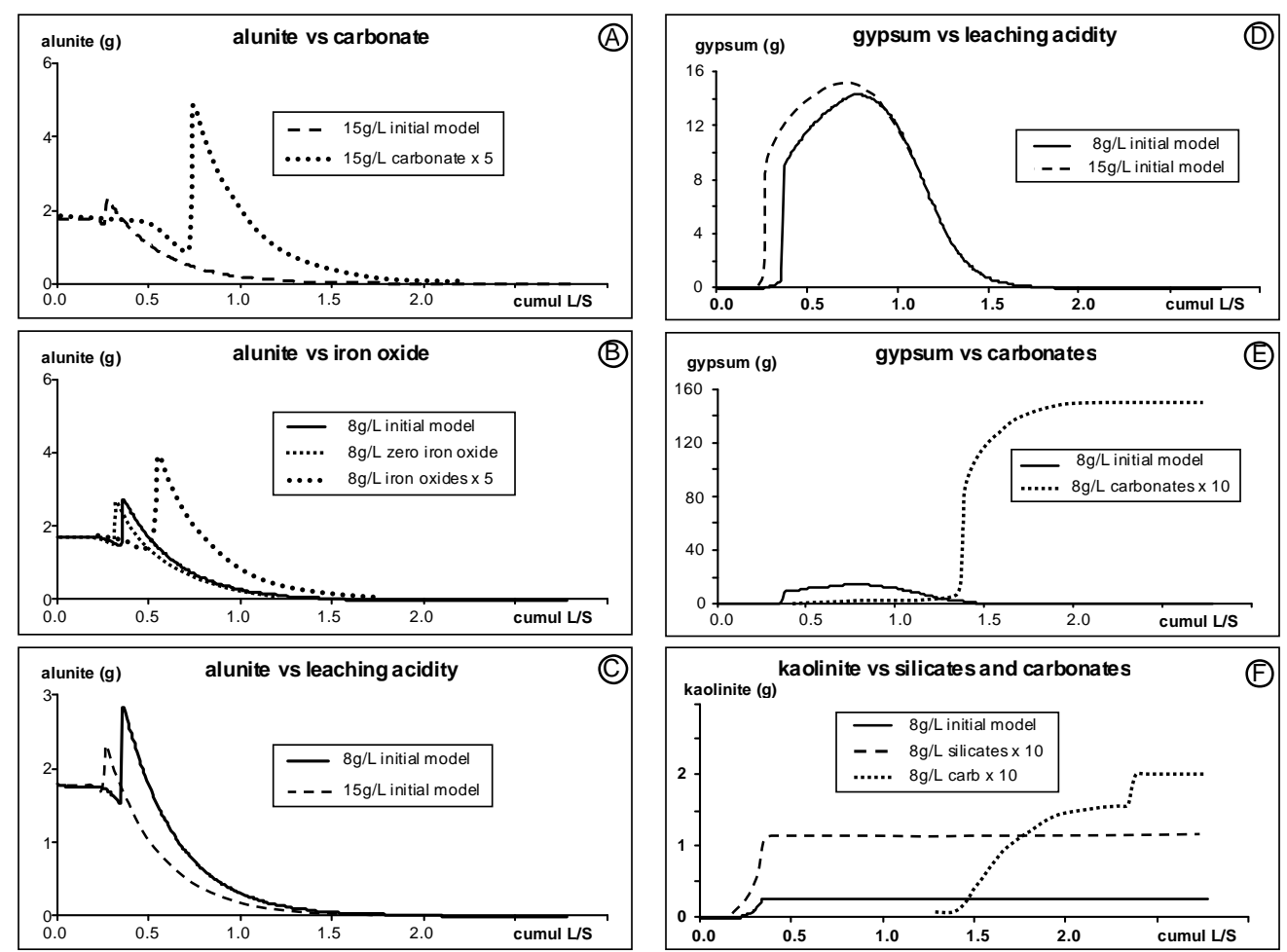

Figure 9: Simulation of the amounts of secondary minerals that precipitate as a function of variations of the mineralogical composition of the ore and the acidity of the leaching solution.

\subsection{Effect of chemically-laden ISR leaching solution}

A simulation test was made with a leaching solution similar to that of the ISR mining operation (Table 7), i.e. containing significantly more calcium, aluminium, iron and sulphates in solution than the "fresh" acidic solution used in laboratory experiments and initial modelling. It shows that:

1) gypsum precipitates earlier with the "recycled" solution and does not dissolve at all, because the recycled solution is saturated in calcium and sulphate with regards to gypsum (Fig. 10A);

2) alunite also precipitates earlier, especially because the recycled solution has a high aluminium concentration (Fig. 10B);

3) uranium recovery is not significantly different from that simulated with the "fresh" solution injection, but is nevertheless somewhat faster; due to the presence of ferric iron in the leaching solution. 
These results show that injection of a solution similar to that used in the ISR mining operation, essentially influences gypsum and alunite precipitation, which may lower porosity in the ore and clog the pumping wells. However, although the recycled leaching solution increases alunite precipitation, alunite dissolution occurs in a volume of percolated solution equivalent to than of a "fresh" acid injection, due to its solubility in acidic conditions (Fig. 10). On the other hand, although equivalent amounts of gypsum are formed for the two tested injection solutions, gypsum dissolution does not occur with a recycled solution, due to its high Ca content which results in a porosity loss in the ore (Fig. 10). In order to limit the porosity loss at the onset of the leaching, it seems that the priority should be to try to limit the precipitation of gypsum (in the case of a carbonate-bearing ore) by making a weaker acid attack at the start of the mining operations.

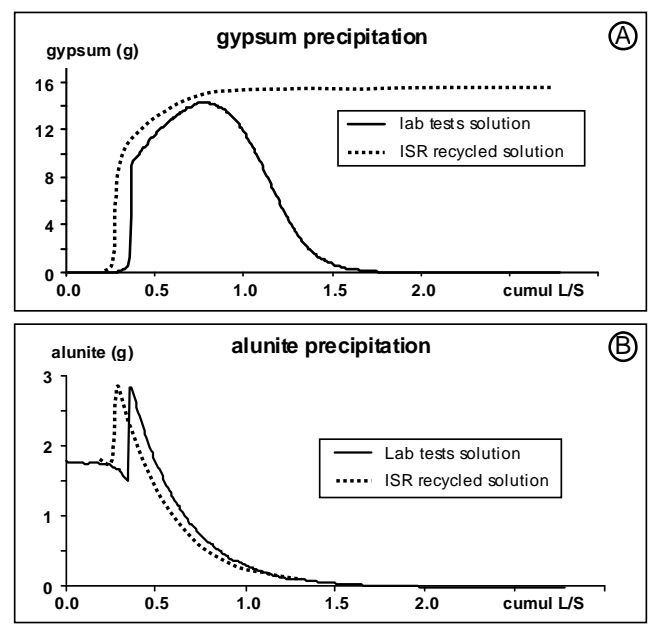

Figure 10: Comparison of leaching simulations performed with sulphuric acid and leaching solution similar to those of the ISR mining operation.

\section{Discussion and conclusion}

Salient points. An attempt was made to limit oxidation during storage by drying samples shortly after drilling but without success. This caused difficulties with leaching test interpretations, since it is difficult to differentiate between the natural in situ mineral assemblage, and that modified by the alteration of samples during storage.

Clay mineral paragenesis was not included in the geochemical model for two main reasons: (1) claystones form low permeability lenses through which the leaching solution do not percolate, and (2) the uranium content in the claystones is not taken into account by the operator in the uranium reserve evaluation. The distribution and potential role of clay minerals should nevertheless be considered in future studies.

Model robustness. The leaching tests were interpreted through a limited number of reactions. Thus, leachate simulations were highly constrained by limited adjustment of only two parameters: (1) mineral abundances were adjusted on batch tests only for minerals present as traces, and (2) reactive surface areas initially calibrated on batch tests were systematically reduced for column simulation due to 
contact between compacted grains. Nevertheless, a single geochemical model was finally able to simulate two types of leaching tests (batch and column) and various leaching solutions, which is satisfactory at least from a modelling point of view.

Uranium recovery. Several factors impacting uranium recovery have been pointed out. Iron oxide content of the ore appears to be the most sensitive factor in terms of volume of leachates that have to be treated for the ISR operation. Indeed, iron oxide dissolution provides $\mathrm{Fe}^{3+}$ in solution, which significantly increases uranium solubility. The carbonate content of the ore deposit is especially sensitive in terms of acid consumption and volume of leachate to be handled on site. For instance, a comparison of the simulation of the leaching of ores containing 0.2 and 2 weight \% carbonates shows that the carbonate-rich ore consumes three times more acid for an equivalent uranium recovery. Moreover, carbonates promote gypsum precipitation leading to a porosity reduction in the ore and to a decrease of uranium recovery efficiency. Higher sulphuric acid concentration leads to greater acid consumption and volume of leachate to be handled, essentially due to stronger silicate dissolution and secondary precipitation (alunite and gypsum). Low pore velocity promotes the dissolution of minerals with slow kinetics, such as silicates, and therefore also increases the acid consumption.

Mining management. The series of simulations led us to make some proposals for mining management. As the solubility of uranium is strongly related to the redox state of the leaching solutions, injection of the leaching solutions in the oxidized zones of the deposit, in order to dissolve iron oxides, will increase recovery efficiency by increasing the redox potential of the solutions. To limit mineral volume increase, and thus potential clogging of pores and wells, a priority should be to limit gypsum precipitation, by a weaker acid attack at the start of the ISR mining operation. However, this strategy interferes with secondary alunite precipitation (possible if $\mathrm{pH}>3$ ) and above all with the uranium production (since a low $\mathrm{pH}$ is needed to solubilise the ferric ions responsible for uraninite dissolution).

The acid consumption may be limited by imposing a stonger injection pressure in order to increase pore velocity and thus limit slow acid-consuming reactions, especially silicate dissolution.

Further model simplification. Future development of a 2D/3D modelling of the ISR operation at fieldscale will require simplifications of the geochemical model. Among potential simplifications, one suggestion might be that dolomite is withdrawn from the mineralogy of the simulated ore, and that only calcite is used to simulate carbonate behaviour. Silicates may also be restricted to a single Kaluminosilicate, due to their slow kinetics.

Support to ISR mining operation. Direct control of the ISR process by operators is at present extremely limited, and its efficiency is difficult to assess, partly because of the delay between injection of the solution into the ore and its withdrawal at pumping wells. Numerical simulations seem to be 
important and promising tools in deciding whether to conduct and optimize this type of mining exploitation in the near future.

Acknowledgements: The research was supported by AREVA NC BU Mine and ANRT (Association Nationale de la Recherche et de la Technonologie) through a CIFRE (Conventions Industrielles de Formation par la REcherche) agreement (n251/2006). The authors also wish to thank Kazakhstan's Joint Venture KATCO for sampling support and help on the Tortkuduk ore, and AREVA-SEPA laboratories in Bessines-sur-Gartempe (France) for providing experimental facilities and sample analysie. The authors wish also to thank two anonymous reviewers how contributed to improve an early version of the manuscript, as well as Pr. Vojtěch Ettler, Associate Editor, for handling the manuscript and revision suggestions.

\section{References}

Ben Simon R., 2011, Tests de lessivage acide de minerais d'uranium et modélisations géochimiques des réactions. Application à la récupération minière in situ (ISR). PhD thesis, Ecole doctorale 398, Géosciences et Ressources Naturelles, Mines ParisTech, 175 p. http://pastel.archivesouvertes.fr/docs/00/65/73/86/PDF/BEN_Simon_Rose_2011.pdf

Bigham J.M., Nordstrom D.K., 2000, Iron and aluminium hydroxisulphates from acid sulphate waters. Rev. Mineral. Geochem., 40, p. 351-403.

Bommer P.M., Schechter R.S., 1979, Mathematical modeling of in-situ uranium leaching. Society of Petroleum Engineers Journal, 19/7, p. 393-400.

Commonwealth of Australia, 2010, Australia's in situ recovery uranium mining best practice guide: groundwaters, residues and radiation protection, Canberra, ISBN 978-1-921672-95-8, ISBN 978921672-96-5, $31 \mathrm{p}$.

Dahlkamp F.J., 2010, Uranium deposits of the World. Chapter 6. Kazakhstan. Springer, p. 191-267.

Deditius A.P., Utsunomiya S., Ewing R.C., 2007, Alteration of $\mathrm{UO}_{2+x}$ under oxidising conditions. Journal of Alloys and Compounds, 444-445, p. 584-589.

Eary L.E., Cathles L.M., 1983, A kinetic model of $\mathrm{UO}_{2}$ dissolution in acid, $\mathrm{H}_{2} \mathrm{O}_{2}$ solutions that includes uranium peroxide hydrate precipitation. Metallurgical Transactions B, 14B, p. 325-334.

Gasharova B., Göttlichera J., Becker U., 2005, Dissolution at the surface of jarosite: an in situ AFM study. Chemical Geology, 215/1-4, p. 499-516.

Jambor J.L., 1994, Mineralogy of sulphide-rich tailings and their oxidation products. In: D.W. Blowes and J.L. Jambor (eds), The Environmental Geochemistry of Sulphide Mine-wastes, Short Course Handbook, 22, p. 59-102.

Johnson R.H., 2011, Reactive transport modeling for the proposed Dewey Burdock Uranium in-situ recovery mine, Edgemont, South Dakota, USA. International Mine Water Association 2011, Mine Water - Managing the Challenges, Proceedings, Aachen, Germany, p. 221-223.

Johnson R.H., Yoshino M.E., Hall S.M., Shea V.R., 2010, Predictive modeling strategies for operations and closure at uranium in-situ recovery mines. International Mine Water Association 2010, Mine Water and Innovative Thinking, Proceedings, September 5-9, 2010, Sydney, Nova Scotia, p 475-478.

Hu G., Dam-Johansen K., Wedel S., Hansen J.P., 2006, Decomposition and oxidation of pyrite, Progress in Energy and Combustion Science, 32/3, p. 295-314

IAEA, 2001, manual of acid in situ leach uranium mining technology, IAEA, VIENNA, 2001, report IAEA-TECDOC-1239, ISSN 1011-4289, 283 p. 
Kuzmanov L., Simov S.D., Valkov T., Vasilev D., 1993, In-Situ Leaching of Uranium in Bulgaria: Geological, Technological and Ecological Considerations. In: IAEA (Ed.), Uranium in situ leaching. Proceedings of a Technical Committee Meeting held in Vienna, 5-8 October 1992, IAEA-TECDOC720, Vienna 1993, p. 65-73

Lagneau V., 2000, Influence of geochemical processes on transport in porous media; application to the clogging of possible confining barriers in a geological repository. PhD thesis, Mines ParisTech, $213 \mathrm{p}$.

Lagneau V., 2010, Reactive transport and waterflow on an Odd Dimension 2 grid - Notice technique et vérification mise à jour pour la version 2.7. Technical Report; Mines ParisTech, R100309VLAG, $108 \mathrm{p}$.

Lagneau V., Jan van der Lee, 2010, Operator-splitting-based reactive transport models in strong feedback of porosity change: The contribution of analytical solutions for accuracy validation and estimator improvement, Journal of Contaminant Hydrology, 112, p. 118-129.

Lottering M. J., Lorenzen L., Phala N. S., Smit J. T., Schalkwyk G. A. C. (2008). Mineralogy and uranium leaching response of low grade South African ores. Minerals Engineering, 21(1), p. 16-22.

Majima H., Awakura Y., Mishima T., 1985, The leaching of hematite in acidic solutions. Metallurgical Transactions B, 16/1, p. 23-30.

McKibben M.A., Barnes H.L., 1986, Oxidation of pyrite in low temperature acidic solutions: Rate laws and surface textures. Geochimica et Cosmochimica Acta, 50, p. 1509-1520.

Mudd G.M., 2001, Critical review of acid in situ leach uranium mining: 1. USA and Australia. Environmental Geology, 41, p. 390-403.

Mudd G.M., 2001, Critical review of acid in situ leach uranium mining: 2. Soviet Block and Asia. Environmental Geology, 41, p. 404-416.

Nigbor M.T., Engelmann W.H., Tweeton D.R., 1982, Case History of a Pilot-Scale Acidic In Situ Uranium Leaching Experiment. United States Department of the Interior, Bureau of Mines Report of Investigations RI-8652, Washington D.C., 81 p.

Nos J., 2011, Modèle conceptuel d'une exploitation d'uranium par récupération in situ. Interprétation des données de production et apport de la modélisation du transport réactif en milieu hétérogène. PhD thesis, Mines ParisTech, $150 \mathrm{p}$.

Palandri J.L., Kharaka Y.K., 2004, A compilation of rate parameters of water-mineral interaction kinetics for application to geochemical modelling. USGS, open file report n2004-1068.

Plummer L.N., Busenberg E., 1982, The kinetics of dissolution of dolomite in $\mathrm{CO}_{2}-\mathrm{H}_{2} \mathrm{O}$ systems at 1.5 to 65 degrees $\mathrm{C}$ and 0 to $1 \mathrm{~atm} \mathrm{pCO}_{2}$, evaluation of the aqueous model for the system $\mathrm{CaCO}_{3}-\mathrm{CO}_{2}-$ $\mathrm{H}_{2} \mathrm{O}$. Geochimica et Cosmochimica Acta, 46/1-2, p. 29-48.

Raines M.A., Dewers T.A., 1997, Mixes transport/reaction control of gypsum dissolution kinetics in aqueous solutions and initiation of gypsum karst. Chemical Geology, 140/1-2, p. 29-48.

Sundar P.S., 1977, In-situ leaching studies of uranium ores: Phases I through III. Technical Report, Westinghouse Electric Corp., Pittsburg, Pa., USA, 403 p.

Torrero M.E., Baraj E., de Pablo J., Gimenez J., Casas I., 1997, Kinetics of corrosion and dissolution of uranium dioxide as a function of $\mathrm{pH}$. International Journal of Chemical Kinetics, 29/4, p. 261-267, DOI: 10.1002/(SICI)1097-4601(1997)29:4<261::AID-KIN4>3.0.CO;2-S.

Van der Lee J., 2003, Reactive transport modeling with HYTEC. User's guide and tutorial. Technical Report, Mines ParisTech, CIG/ARMINES, LHM/RD/03/10, 63 p.

Van der Lee J., De Windt L., 2002, CHESS tutorial and cookbook, updated for version 3.0. User's manual. Technical Report, Mines ParisTech, CIG/ARMINES, LHM/RD/02/13, $112 p$ 
Van der Lee J., De Windt L., Lagneau V., Goblet P., 2003, Module-oriented modeling of reactive transport with HYTEC. Computers \& Geosciences, 29, p. 265-275

Wood S., 1978, Characterization of the uranium occurrence in pre-and post-leach ore samples from sandstone deposits in Texas \& Wyoming. SPE, Society of Petroleum Engineers of AIME, 7537, p. 1-8.

World Nuclear Association, 2012, http://www.world-nuclear.org/info/inf23.html

Xu T., Apps J.A., Pruess K., 2004, Numerical simulation to study mineral trapping for CO2 disposal in deep aquifer. Applied Geochemistry, 19/6, p. 917-936. 